\title{
A REVIEW OF THE TRIGGER-FISHES, FILE-FISHES, AND TRUNK-FISHES OF JAPAN.
}

\author{
By David Starr Jordan and Henry W. Fowler, \\ of the Leland Stanford Junior University.
}

In the present paper is given an account of the Plectognathous fishes, found in Japan, belonging to the suborders of Sclerodermi and Ostracodermi. The paper is based on the collections made by Jordan and Snyder in 1900, and on the material contained in the United States National Museum, and collections made by the United States Fish Commission steamer Albatross.

\section{SCLERODERMI.}

Sclerodermi may be defined as Plectognathous fishes with a spinous dorsal composed of one or more spines inserted just behind the cranium; body of the normal fish-like shape; scales rough, or spinigerous, of regular form; jaws with distinct teeth, conical or incisor-like.

( $\sigma \kappa \lambda \eta \rho o ́ s$, hard; $\delta \varepsilon ́ \rho \mu \alpha$, skin.)

\section{ANALYSIS OF FAMILIES.}

a. Ventral fins represented each by a large spine, normally articulating with the pelvic bones; scales rounded, more or less spinigerous; dorsal fin of 3 to 6

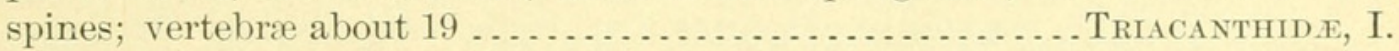

aa. Ventral fins obsolete, or the pair represented by a single spine at the end of the long pelvic bone; scales rough, rhombic, or spiniform.

b. Vertebræ in small number, 17 to 21 ; no barbel at chin; gill opening not before the eyes.

c. First dorsal composed of 3 , rarely 2, spines; the first spine very large, the second locking it in erection; scales comparatively large, bony, rough,

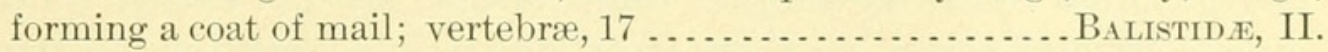

$c c$. First dorsal of a single spine, with a rudiment at its base; scales minute, not bony, the edges spinescent, so that the surface of the body is rough velvety;

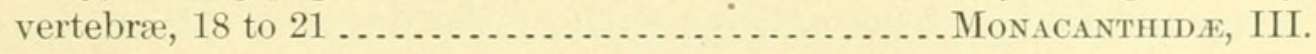

\section{Family I. TRIACANTHIDA.}

Body compressed, covered with small or minute rounded scales more or less spinigerous. Mouth small; teeth in 1 or 2 series in each jaw, conical or incisor-like. First dorsal fin of 3 to 6 strong spines, the 
first one largest; soft dorsal rather long and low, similar to anal; ventral fins each a strong spine attached to the pelvic bone; vertebræ (in Triacanthus) $9+10=19$. Three genera and about 5 species; tropical shore fishes, chiefly East Indian, one of them American.

a. Triacanthodinx: Teeth small, close-set, conical, not incisor-like; caudal peduncle short; dorsal spines strong, not very unequal.

$b$. Teeth in two rows in each jaw, the upper jaw with about 14 teeth in the outer row, the lower with 22 ; inner series with about 2 teeth.... Triacanthodes, 1.

aa. Triacanthinx: Teeth incisor-like, in two series in each jaw, those of the outer row prolonged, about 10 in number, the inner series with 2 or 4 ; caudal peduncle produced, slender; first dorsal with 3 or 4 small spines behind a very

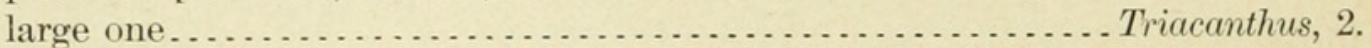

\section{TRIACANTHODES Bleeker.}

Triacanthodes Bleeker, Act. Soc. Sci. Indo. Nederl., III, 1857, Japan, IV, p. 37 (anomalus.)

Body short, compressed, with short tail, covered with small spiny scales; teeth small, conical, close set, in two series, about 14 to 22 , two small teeth in the inner series. Lateral line inconspicuous. Dorsal spines about 5, strong, not very unequal, rough on their basal halves. Ventrals each a strong spine attached to the pelvic bone, besides two slender soft rays. Soft dorsal of about 15 rays; anal of about 12.

(triacanthus: $\varepsilon \tilde{i} \delta o s$, resemblance.)

\section{TRIACANTHODES ANOMALUS (Schlegel).}

\section{BENI KAWAMUKI (RED FILE FISH).}

Triacanthus anomalus Schlegel, Fauna Japonica Poiss., 1846, p. 295, pl. cxxix, fig. 3; Nagasaki.-Nystrom, Svensk. Vet. Ak., 1887, p. 47; Nagasaki.

Triacanthodes anomalus Bleek er, Act. Soc. Sci. Indo. Nederl., III, 1857, Japan, IV, p. 37; Nagasaki.—Günther, Cat. Fish., VIII, 1870, p. 208; Japan.

Depth $2 \frac{1}{3}$; head little over 3 ( 4 in total); D. IV to VI, 14 to 16 ; A. 12 to $13 ;$ V. I, 2 . Snout $2 \frac{1}{2}$ in head. Jaws with a single series of from 18 to 20 small teeth, pointed, somewhat conical and curved. Body compressed and roughened. Pectorals rounded, $1 \frac{2}{3}$ in head. First dorsal spine almost as long as the head. Dorsal and ventral spines strong, rough on their basal halves. Ventral spines roughened and as long as the first dorsal spine. Anal beginning a little behind anus and its height equal to a fifth of the depth of the body. Second dorsal larger than anal and its height 3 in the depth of the body. Caudal rounded and equal to the snout with eye. Color reddish, brighter above and whitish below. Length 3 to $4 \frac{1}{2}$ inches. (Schlegel, Bleeker, Günther.)

This little fish, which reaches a length of 4 or 5 inches, is recorded by Schlegel as taken only in May about the rocks at the mouth of the 
bay of Nagasaki. It is much valued as a food fish and is eaten raw with a sauce of sake or rice brandy. No specimens were taken by Jordan and Snyder.

(anomalus, anomalous.)

\section{TRIACANTHUS Cuvier.}

Triacanthus Cuvier, Règne Animal, 1st ed., 1817, p. 152 (biaculeatus).

Body more or less elongate, compressed, covered with minute rough scales; tail slender, prolonged; teeth in two series in each jaw; those of the outer row incisor-like, ten in number, those of the inner row more rounded, two or four in number. First dorsal of one very strong rough spine and several short ones. Ventral fins each of a strong spine attached to the pubic bone; soft dorsal of about 24 rays, anal of about 19; lateral line conspicuous.

( $\tau \rho \varepsilon \tilde{\imath} s$, three; $\ddot{\alpha} \kappa \alpha \nu \theta \alpha$, spine.)

\section{TRIACANTHUS BREVIROSTRIS Schlegel.}

GIN-KAWAMUKI (SILVERY FILEFISH).

Triacanthus brevirostris Schlegel, Fauna Japonica, Poiss., 1846, p. 294, pl. cxхıx, fig. 2; Nagasaki.-Hollard, Ann. Sci. Nat., I, 1854, p. 45, pl. II, fig. 1.Bleek er, Atlas Ichth. Balist., 1865-69, pl. xvir, fig. 3; Java, Madura, Sumatra, Singapore, Borneo, Celebes, Amboyna, etc.-Günther, Cat. Fish., VIII, 1870, p. 209; Japan, Formosa, Amboyna, Madras, China.-Ishikawa, Prel. Cat., 1897, p. 4; Kagoshima, Suruga.

Triacanthus rhodopterus BleEk ER, Verh. Bat. Gen., XXII, 1849, p. 25, pl. Iv, fig. 8. Triacanthus russelli Bleeker, Verh. Bat. Gen., XXII, 1849, p. 25; Coromandel (after Patrick Russell).

Triacanthus brachysoma Bleeker, Nat. Tyds. Ned. Ind., IV, 1853, p. 128.

Balistes bipes Gronow, Cat. Fish., Ed. Gray, 1854, p. 37; East Indies.

Head about 4 ; depth 2 to $2 \frac{4}{5}$; snout $1 \frac{1}{2}$, and eye 3 to 4 in head; D. V, 22 to 25 ; A. 17 to 20 . Maxillary 10 in external series, incised or cuneiform, and inner series obtusely rotundate. Snout not produced, with the upper profile nearly straight. Pectorals rounded, short. First dorsal spine strong, covered with asperities; ventral spines long. Second dorsal a little lower than the longest anal ray. Color above greenish or bluish gray, below silvery or yellowish; head above, greenish; spinous dorsal with a black blotch. Length, 11 inches. (Schlegel, Bleeker, Günther.)

Bleeker regards Triacanthus nieuhofi with a depth of 2 to 3 (total length) as distinct from Triacanthus brevirostris, which has a depth of 3 to $3 \frac{1}{2}$ (total length).

This species, common in the East Indies, is rare in Japan, being recorded from the southern region only. In the Imperial Museum are specimens of this species from Suruga Bay and from Kagoshima. No specimens taken by Jordan and Snyder.

(brevis, short; rostrum, snout.) 


\section{Family II. BALISTID A.}

TRIGGER FISHES.

Body oblong, or ovate, moderately compressed, covered with rather large rough scales or scutes of varying form, the scutes not forming an immovable carapace. Laterai line obscure or wanting. Mouth small, terminal, low; jaws short, each with about 1 series of separate incisor-like teeth; eye near occiput; preorbital very deep. Chin without barbel. Gill openings small, slit-like, above or in front of pectoral fins, and not before eyes. Dorsal fins 2, the anterior of 2 or 3 spines, the first spine highest, very strong, the second locking it in erection; second dorsal remote from the first, of many soft rays; caudal fin rounded or forked; ventral fins wanting, their place occupied by a single stout, thick spine at the end of the very long, usually movable pubic bone. Post-temporal short, simple, the forks obliterated, the bone grown solidly to the skull, and with no foramen. Vertebræ in reduced number (17). Shore fishes of the tropical seas, of rather large size, carnivorous, or partly herbiverous, very rarely used as food, many of them reputed to be poisonous.

a. Caudal peduncle compressed.

$b$. Teeth white or pale, not red.

c. Teeth unequal, oblique, each one deeply notched.

d. Gill opening with a number of enlarged bony plates or scutes behind it; ventral flap movable, supported by a series of spines, more or less free at tip, and resembling fin rays.

$e$. Dorsal and anal fins low and rounded, their angles and those of caudal not produced; lateral line obsolete or with a trace at the shoulder; scales of posterior parts each with a blunt spine or tubercle; ventral flap narrow, its supporting spines stout and thick in the adult; third dorsal spine small.

$f$. Eye with a naked groove before it.

g. Cheeks with small scales closely set; snout scaly ......Pachynathus, 3. gg. Cheeks with large scales loosely set; snout naked... Pseudobalistes, 4.

ff. Eye without preocular groove..................... Balistapus, 5 . $d d$. Gill opening with only ordinary scales behind it; no enlarged plates or scutes; ventral flap scarcely movable, its surface scaled; lateral line obsolete; third dorsal spine small or wanting; vertical fins in adult more or less angulate or falcate.

$h$. Chin not projecting; cheeks closely scaled; dorsal spine 3 ; scales of posterior parts unarmed or keeled Canthidermis, 6 .

\section{PACHYNATHUS Swainson.}

Pachynathus Swarnson, Classn. Fishes, II, 1839, p. 326 (triangularis=capistratus; the name evidently an error for Pachygnathus, but not so spelled; not Pachygnathus, an earlier name of a genus of spiders.)

This genus differs from Balistes in the rounded outlines of the vertical fins and in the possession of small spines or tubercles on the scales of the caudal region. Ventral flap somewhat movable, its sup- 
porting spines short and very thick. Lateral line reduced to a trace at the shoulder. Species few, inhabiting the Pacific, intermediate between Balistes and Balistapus. The name Pachynathus is, perhaps, ineligible, as if spelied correctly it is preoccupied.

( $\pi \alpha \chi v^{\prime} s$, thick; $\gamma v \alpha \dot{\theta} \theta o s$, jaw.)

a. Color olivaceous, with a pale ring about the mouth and usually a pale line behind it; caudal double truncate; D. III, 29; A. 28; scales $50 \ldots . . . .$. capistratum, 3. aa. Color dusky with a green area marked by dark spots above; lower parts with large round blotches of dull red; a blue ring about snout; caudal rounded.

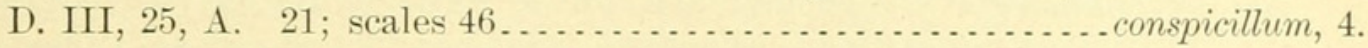

\section{PACHYNATHUS CAPISTRATUM (Shaw).}

Le Baliste bridé Lacépède, Hist. Nat. Poiss., I, 1798, p. 335; without locality; on a drawing by Commerson.

Balistes capistratus Shaw, Genl. Zool., V, 1804, p. 417 (after Lacépède; not Pachynathus capistratus Jordan and Evermann, which is a distinct species, with smaller scales, =Pachygnathus verres Gilbert and Starks.)

Balistes mitis Bennett, Proc. Comm. Zool. Soc., I, 1831, p. 169; East Indies.Günther, Cat., VIII, 1870, p. 218.

Balistes amboinensis Gray, Hardwicke, Illus. Indian Zool., 1834; Amboyna.

Pachynathus triangularis Swarnson, Classn. Fishes, II, 1839, p. 326 (Vizagapatam, after Russell, pl. xx.)

Balistes hihpe Richardson, Voy. Sulphur, Fishes, 1843, p. 127; East Indies.

Balistes frenatus Richardson, Voy. Sulphur, Fishes, 1843, p. 129; East Iindies.Bleeker, Atlas Ichth., 1865-69, pl. cccxxiri.

Balistes schmittii Bleeker, Verh. Bat. Gen., XXIV, 1852, p. 37; Sumatra.

Head $2 \frac{2}{3}$; depth 2; D. III, 28 to $30 ;$ A. 25 to 27 ; scales 50 . Body rather oblong, a groove before the eye. Each scale for about 9 rows on the tail and posterior part of sides, with a small, smooth, inconspicuous tubercle; about 34 scales in several parallel horizontal streaks in front of pectoral, a transverse series from soft dorsal to vent; a few bony scutes behind the gill opening, 1 of these considerably enlarged. Lateral line obsolete, reduced to a few scales behind eye. Dorsal and anal fins rather low, with outlines rounded or slightly angular in front, the first rays not produced; the caudal double truncate, the angles scarcely produced. First dorsal spine strong, very rough, especially above. Ventral flap small, movable, supported by several short, thick spines. Uniform blackish brown; a yellowish ring from middle of upper lip around the lower jaw, a straight yellow stripe from this ring toward the pectoral, not reaching the gill opening; this sometimes absent or indistinct. Pacific Ocean; widely distributed through the East Indies and on the coast of China. Here described from an adult example from Wakanoura.

This species is very abundant in the East Indies and westward to Honolulu. One specimen secured at Wakanoura, and another was obtained for us by Yonekichi Koneyama, who caught it at Nafa in Okinawa. There are no other records from Japan, but we have many examples from Hawaii. 
The American species, heretofore called Pachynathus capistratum, is different from Japanese or Hawaiian specimens, having larger scales. It has been named Balistes verres by Gilbert and Starks.

(capistratus bridled.)

\section{PACHYNATHUS CONSPICILLUM (Bloch and Schneider).}

\section{MONGARA KAWAHAGI (SPOTTED SKIN PEELER), KOMONIUWO (BLOTCHED FISH).}

Balistes conspicillum Bloch and Schnerder, Syst. Ichth. Bloch, 1801, p. 474; Indian Seas (after Guaperva tacheté of Sonnerat).- Schlegel, Fauna Japonica, 1846, p. 289, pl. сxхIx, fig. 1; Nagasaki.-Bleek ER, Atlas Ichth. Balist., 1865-69, p. 116, pl. vir, fig. 2.-Gǜther, Cat. Fish., VIII, 1870, p. 220; Japan, Formosa.-Namiye, Cat. Spec. Vert., 1881, p. 113, Kishin.-Ishikawa, Prel. Cat., 1897, p. 4, Kagoshima.

Balistes bicolor Sнаw, Gen. Zool., V, 1804, p. 407, pl. II.

D. III, 25 to 26 ; A. 21 to 22 ; scales in lateral line 46 , or about 50 to 55 from gill opening to middle part of caudal. Eye 4 to 6 in head, $2 \frac{1}{2}$ to 4 in snout. Head higher than long; lips broad and fleshy; patch of enlarged scales 3 or 4 in number behind the gill opening; about 29 scales in a transverse section from the origin of the dorsal to the vent; dorsal and anal rather low; caudal subtruncate; ventral spine very short and movable; two and a half series of tubercles on caudal peduncle; caudal rounded, the angles not produced; lateral line not conspicuous. Color brownish or black, with very large, round, yellow spots on the lower part of the body in 4 longitudinal series. Back between dorsals of a lighter coloration. The center of each scale brown and the edges yellowish; a yellowish band across the snout from one eye to the other; extremity of the snout orange and with a narrow orange ring; pectorals with yeliow or orange rays; spinous dorsal brown or blackish; soft dorsal and anal grayish blue and with orange bases; caudal black at base, medianly clear yellow, with a marginal black band. Length 13 inches. (Schlegel, Bleeker. Günther; the color after Schlegel.)

This species is occasionally taken in the Kuro Shiwo, off the coast of Japan and southward. It is recorded from Nagasaki and Kagoshima, and we have examined a specimen from Urakawa, in Hokkaido, preserved in the museum at Hakodate. This has: D. III, 24; scales 44. A specimen from Kii is in the Imperial University.

(conspicillum, a pair of spectacles, in ailusion to the round spots.)

\section{PSEUDOBALISTES Bleeker.}

Pseudobalistes Bleek er, Atlas Ichth. Balist., III, 1865-69, p. 113 (flavimarginatus)

This genus differs from Pachynathus in the large size of the scales on the cheek, which do not cover the whole surface, though not leaving the naked stripes seen in Parabalistes. Snout naked. Caudal 
lunate, but not deeply forked. Dorsal and anal low, as in Balistapus. Scales of the tail with tubercles. Pacific Ocean.

$\left(\psi \varepsilon v \delta \eta^{\prime} 5\right.$, false; Balistes, from $\beta \alpha \lambda \imath \sigma \tau \eta_{5}$, shooter, which is from $\beta \alpha \dot{\alpha} \lambda \lambda_{\omega}$, to shoot with a crossbow; in allusion to the trigger-like third spine, which sets or releases the first spine, as in a crossbow.)

\section{PSEUDOBALISTES FLAVIMARGINATUS (Rüppell).}

\section{SURUMICHI.}

Balistes flavimarginatus RüPPELr, Atlas Fische, 1828; p. 33; Red Sea.-BleEk ER, Atlas Ichth. Bal., 1865-69, p. 113, pl. Iv, fig. 3; pl. x, fig. 3.-GüNTHER, Cat. Fish., VIII, 1870, p. 223; Red Sea, Amboyna.-Ishikawa, Prel. Cat., 1897, p. 4; Riukiu Islands.

Balistes beeri Bleek er, Act. Soc. Sci. Indo-Neerl, V. 1856, Celebes, p. 53; Celebes.

D. III. 26 to 27 ; A. 23 to 25 ; scales in lateral line 35 to 36 . Eye 3 to 5 in head, $1 \frac{1}{3}$ to 4 in snout. Lips broad and fleshy; snout partly naked; interorbital space strongly convex; 3 or 4 osseous seutes behind the gill opening; about 20 scales in a transverse series from the origin of the dorsal to the vent; soft dorsal and anal somewhat elevated; caudal rounded in very young, truncate in half-grown and deeply emarginate, with produced lobes in adult examples; ventral spine short, movable; on the caudal peduncle 4 to 6 series of rather small recurved spines. Color of adult, yellowish or violet green, without conspicuous spots, nearly uniform; fins except spinous dorsal blackish violet on the basal part, the outer extremities yellowish, crossed by a longitudinal blackish-violet bar; spinous dorsal reddish, margin black, in half grown examples yellowish or brownish orange; numerous blackish or brownish spots on trunk; posterior fins olivebrown, margined with yellow; young, brownish above, below pale yellow; spotted on the sides; base of spinous dorsal blackish; the fins yellow. Length, 23 inches. (Bleeker, Günther.)

Of this species, common in the East Indies, we have one small specimen, $1 \frac{1}{4}$ inches long, from Wakanoura. Head $2 \frac{1}{2}$ in length; depth $1 \frac{2}{3}$; eye large, $1 \frac{2}{3}$ in snout; edges of snout without scales; cheeks less closely scaled than the rest of the head; pectorals whort; ventral spine very rough; caudal rounded; upper surface of the head, basal dorsal spines and back blackish; several dark bars at base of caudal; sides of the body spotted with blackish.

(flavus, yellow; marginatus, edged.)

\section{BALISTAPUS Tilesius.}

Balistapus Tilesıus, Mém. Ac. Nat. Sci., Petersb., about 1812, VII, p. 301 (capistratus of Tilesius, not of Shaw, undulatus).

Rhinecanthus Swainson Classn. Anim., II, 1839, p. 325 (ornatissimus=aculeatus).

This genus has the head and body closely scaled, the scales of the posterior parts more or less spinous; enlarged scales behind the gill

Proc. N. M. vol. $\mathrm{xxv}-02-17$ 
opening, the lateral line obsolete and no groove before the eye. The species are numerous in the Indian seas. They are small and rather brightly colored.

(balistes, $\ddot{\alpha} \pi$ ovs, footless.)

a. Body covered from snout to tail with many oblique wavy reddish lines; D. III, 25, A. 24; scales 50; spines on tail in a black patch ............ undulatus, 6 . aa. Body greenish above, brownish or whitish below; 4 or 5 oblique stripes on sides posteriorly; 3 blue stripes vertically from eye; the colors anteriorly separated by a blue line; 3 blue stripes vertically from eye; a pale patch under caudal

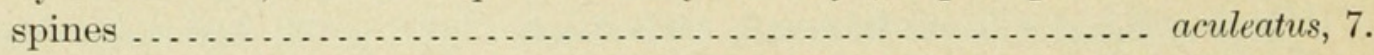

\section{BALISTAPUS UNDULATUS (Park).}

\section{TOKUSA ZAME (SCOURING RUSH SHARK).}

Balistes undulatus Mungo Park, Trans. Linn. Soc., III, 1797, p. 37.-Günther, Cat. Fish., VIII, 1870, p. 226; Red Sea, Zanzibar, Moluccas, Sumatra, Amboyna, Ceram, Cebu, Louisiades, China, Japan.

Balistes lineatus Bloch and Schnember, Syst. Ichth., 1801, p. 466, pl. LXxxvir. Coromandel.-Bleek ER, Atlas Ichth., 1865-69, p. 118, pl. xv, fig. 2.

Balistes aculeatus viridis Bennetr, Fish, Ceylon, 1830, pl. $\mathrm{x}$; Ceylon.

Balistes lamourouxi Quoy and Garmard, Voy. Uranie Zool., 1824, p. 208, pl. XLVII, fig. 1 .

Balistes sesquilineatus Bennetr, Beechey's Voy., 1839, p. 69, pl. xxi, fig. 3; Tahiti. Batistes porcatus Gronow, Syst., Ed. Gray, 1854, p. 32; Indian seas.

Head 3; depth $1 \frac{3}{4}$; D. III., 25 to 27 ; A. 22 to 24 ; scales in lateral line 41 , or about 50 from gill opening to under part of caudal; no groove before eye; eye $3 \frac{1}{2}$ to $5 \frac{1}{2}$ in head, 2 to 4 in snout. Head higher than long, slightly concave above; lips broad and fleshy; jaws equal; patch of 4 enlarged scales behind gill opening. A transverse series of 24 scales running from the origin of the dorsal fin to the vent; dorsal and anal fins rather low, with rounded profile; caudal fin subtruncate; pectoral obtusely rounded; ventral toothed; double series of lateral spines, 4 to 8 in number, on the caudal peduncle. Color bluish-violet, fin rays yeilow or golden-rose; membranes hyaline-blue or violet; head and body with numerous oblique and somewhat undulated reddish or yellowish stripes, two broader than the others, proceed from the lips and are confluent posteriorly; spinous dorsal reddish with brownish yellow and black margins; the spines on each side of the tail in a black patch; base of caudal washed with blackish. (Bleeker, Günther.)

Of this species Günther records a stuffed specimen from Japan, probably from the Riukiu Islands. Another from unknown locality is in the Imperial Museum at Tokio. It is common in the East Indies. (undulatus, waved.) 


\section{BALISTAPUS ACULEATUS (Linnæus).}

Balistes aculeatus Linnwus, Syst. Nat., 10th ed., 1758, p. 328; India.-Bleeker, Atl. Ichth. Balist., $1865-69$, p. 120,1866 , pl. II, fig. 3; East Indies, on all islands (and of all writers).-Günther, Cat. Fish., VIII, 1870, p. 223; Ile de France, Johanna, Zanzibar, Moluccas, Amboyna, China, Fiji, Seychelles, Mauritius.

Balistes ornatissinus Lesson, Voy. Coquille, I, 1824, p. 119, pl. x, fig. 1.

Balistes armatus Cuvier, Règne Anim. Illust., pl. cxir, fig. 2.

Balistés striatus Gronow, Syst., Ed. Gray, 1854, p. 32; American seas.

Head $2 \frac{3}{4}$, depth $2 \frac{1}{4}$, D. III. 25 ; A. 22 ; scales 44 in the lateral line. Body oblong, elliptical, no groove before the eye. On the sides of the caudal peduncle are 3 rows of strong spines, directed forward, consisting of 11, 9, and 5, respectively. Head long, angular, and deeper than long; the snout very long, nearly as long as the head, slightly convex; eye small and high up, $6 \frac{1}{2}$ in head, $5 \frac{2}{3}$ in snout, and $1 \frac{2}{3}$ in interorbital space; interorbital space moderately convex; lips broad, thick, and fleshy; corners of mouth fleshy for some distance backward; snout not scaled; teeth large and strong, the middle the larger, then diminishing toward either end, wedge shape, the ends wider than the bases, the cutting edges notched, and in the upper jaw 8 in the outer and 6 in the inner series, the latter with their edges rounded; in the lower jaw 8 in a single series; the upper jaw closes outside the lower; gill opening equal to interorbital space, and with 4 enlarged bony scales behind; scales 29 in a transverse series from spinous dorsal to anal; pectoral one-fourth longer than gill opening; first dorsal spine very robust, larger than pectoral; dorsal and anal highest anteriorly, rounded; caudal subtruncate; ventral movable, very rough and with several strong spines behind; ridge of belly before ventral also very rough; caudal peduncle deeper than broad and a little less than the interorbital space; body not very rough; the scales largest on the trunk.

Color in spirits pale brownish above, lighter below; spinous dorsal, large patch on sides behind gill opening sending a line to space between the dorsals and another broader track to posterior half of soft dorsal, dark brown; broad band across interorbital space grayish brown with 3 dark-brown bars across from one eye to the other, the narrower interspaces bluish, a brown band from eye to base of pectoral edged narrowly with grayish and a narrow gray or bluish line from eye running convexly to lower base of pectoral, a brownish bar from naked region at corner of mouth nearly to pectoral, with a wash of grayish white below; sides of belly from behind and below enlarged scales behind gill opening to vent, together with 4 posterior oblique bars running in the same direction and patch on caudal peduncle in which spines are placed, white; some black about the bases of the caudal spines; vent and narrow stripe at base of pectoral in front blackish brown; fins 
all plain. Total length $9 \frac{7}{8}$ inches. Here described from a specimen from Okinawa.

This species is very common throughout the East Indies and the equatorial islands of Polynesia as far as Hawaii. It is represented in our collection by one large example from Nafa, in Okinawa, collected by Y. Koneyama. There is no other record from Japan.

(aculeatus, bearing spines or needles.)

\section{CANTHIDERMIS Swainson.}

Canthidermis Swarson, Classn. Anim., 1839, II, p. 325 (angulosus=maculatus).

This genus differs from Balistes chiefly in having the gill opening surrounded by ordinary scales, there being no developed bony scutes behind it. Body much more elongate than in Balistes; dorsal spines 3 ; dorsal and anal elevated in front; caudal with its angles acute; scales moderate, not very rough; scales of caudal peduncle unarmed, or with a medium spine; cheeks completely scaled; a naked groove before eye. Species inhabiting both Indies.

( $\alpha^{\prime} \kappa \alpha \nu \theta \alpha$, spine; $\delta \varepsilon ́ \rho \mu \alpha$, skin, the word, as usual, misspelled by Swainson.)

\section{CANTHIDERMIS ROTUNDATUS (Procé).}

Balistes rotundatus Procé, Bull. Soc. Philom., 1822, p. 130; Manila (“D. III. 26,

A. 21. Scales equal; tail unarmed, brown with black spots.")

Balistes azureus Lessox, Voy. Coquille, II, 1824, p. 121, pl. x, fig. 2.

? Balistes angulosus Quoy and Gamard, Voy. Uranie, Zool., 1824, p. 210.

Balistes oculatus Gray, Hardwicke's Illustr. Ind. Zool. Fish., 1832, pl. vin, fig. 1;

India.-Bleeker, Atlas Ichth. Balist., 1865-69, p. 121, pl. Iv, fig. 2.

?? Balistes adspersus Tschudi, Fauna Peruana, 1846, p. 31; Peru.

Balistes senticosus Richardson, Voy. Samarang, Fish., 1850, p. 23, pl. Ix, figs. 5-8; China Sea.

Balistes maculatus GüNther, Cat. Fish., 1870, VIII, p. 214; Cape of Good Hope,

Pinang, Borneo, Sandalwood Island, China, Japan (in part, not of Bloch, whose type came from the West Indies).-DAY, Fish, India, p. 687, 1878, pl. CLxxxvi, fig. 3; Madras.

B. IV. D. III., 26 or 27 ; P. 15 ; A. 24 or 25 ; C. 12 ; scales 46 to 55 ; L. tr. 28; length of head $3 \frac{2}{3}$ to 4 ; of caudal fin $6 \frac{1}{2}$ to 7 , height of body $2 \frac{1}{2}$ to 3 in total length; eye 2 to $2 \frac{1}{2}$ diameters from end of snout and 2 apart. A groove in front of eye. Teeth uneven, notched. First dorsal fin commences above gill opening, its anterior spine strong and nearly $\frac{1}{2}$ as long as head; ventral spine usually movable; posterior edge of caudal convex or undulated; second dorsal and anal high anteriorly, especially in adults. Cheeks entirely scaled; no osseous scutes behind gill opening. Scales rough and granulated, but without spines or prominent tubercles, except in the immature. Bluish black young examples are covered with numerous light blotches, more especially on lower half of body, these spots are less numerous and larger in adults; dorsal spines black; eyes hazel. Indian and Pacific oceans. It is very common at Madras, attaining at least 16 inches in length. 
This species is common in the East Indies, and one (Day) young example has been recorded by Dr. Günther from Japan, probably from the Riukiu Islands. The proper specific name is uncertain, as the oldest specific name in this group, Canthidermis maculatus, belongs to an American species. The earliest name applicable seems to be rotundatus applied by Manon de Procé to a specimen from Manila. The species must be rare or casual in Japan. No examples were taken.

(rotundatus, rounded.)

\section{Family III. MONACANTHIDA.}

\section{FILE FISHES.}

Body much compressed, covered with very small rough scales, forming a rough or velvety covering; males sometimes with spines on the caudal peduncle; these either robust or needle-like. Upper jaw with a double series of incisor-like teeth, 6 in the outer and 4 in the inner series; lower jaw with 6 similar teeth in a single series; first dorsal with a single strong spine and generally a rudimentary one behind it; second dorsal long, similar to anal; ventral fins reduced to a single osseous, fixed or movable, small appendage at the end of the long pelvic bone; this appendage often rudimentary or entirely absent; no barbel; vertebræ $7+11$ to $14=18$ to 21 . Herbivorous shore fishes of the warm seas, closely allied to the Balistidx, differing chiefly in having the first dorsal represented by a single spine, behind which is sometimes a rudiment; scales small, spinigerous, the skin mostly rough velvety. The species are mostly small in size and are not used for food, having little flesh and that of a bitterish taste, containing poisonous alkaloids producing the disease known as Ciguatera.

a. Pubic bone with a small spine at its end; gill opening short, nearly vertical; dorsal and anal moderate, each of less than 40 rays.

b. Pelvic spine movable, dorsal spine with two series of retrorse barbs, the posterior pointing downward and backward.

c. Abdominal flap developed into a broad fan supported by branched rays and extending far beyond the pelvic spine.................. Monacanthus, 7 .

$c c$. Abdominal flap little developed, extending little beyond the pelvic spine, and with inconspicuous rays ...................... Stephanolepis, 8 .

$b b$. Pelvic spine fixed; dorsal spine with strong barbs behind, with usually smaller barbs in front.

d. Body oblong and elliptical; depth of body less than half length to base of caudal; dorsal and anal usually with more than 30 rays each.

Pseudomonacanthus, 9.

dd. Body short and deep; depth of body more than half length to base of aa. Pelvic bone without spine at its end. caudal; dorsal and anal relatively short............... Rudarius, 10.

e. Dorsal and anal short, each of less than 30 rays, body rather plump.

$f$. Body subcircular; dorsal spine rough, without barbs, inserted over the

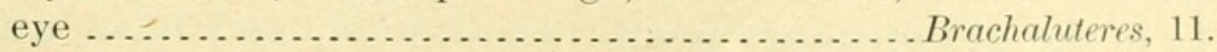

ff. Body oblong; dorsal spine smooth, enveloped in skin, adnate to the back, and inserted behind eye .................. Paraluteres, 12 . 
$e e$. Dorsal and anal very long, each of 36 to 50 rays; body lean and strongly compressed; dorsal spine without barbs; gill opening long, oblique.

g. Dorsal spine feeble, inserted over the eye; dorsal rays about 45 .

h. Caudal fin short, subtruncate, anterior profile convex ...Alutera, 13. $h h$. Caudal fin elongate, rounded, or lanceolate; anterior profile concave, the snout very long.................... Osbeckia, 14 .

gg. Doral spine straight, inserted well in advance of eye; dorsal rays about $43 \ldots \ldots \ldots \ldots \ldots \ldots \ldots \ldots \ldots$. . . . . . . . . . . . . .

\section{MONACANTHUS Cuvier.}

Monacanthus Cuvier, Règne Animal, 1st ed., 1817, p. 152 (chinensis.)

Body short and deep, very strongly compressed, covered with minute, rough scales, the anterior profile more or less concave. Mouth very small; upper jaw with a double series of incisor-like teeth, usually 6 in the outer and 4 in the inner series; lower jaw with about 6 incisors in a single series; teeth connivent, unequal; gill opening a small slit, shorter than the eye, and just in front of upper edge of pectoral. Dorsal spine large, armed with 2 series of retrorse barbs, and no conspicuous filaments; second dorsal and anal fins similar to each other, of about 25 to 35 rays each; caudal fin moderate, rounded; pelvic bone with a blunt, movable spine, the bone connected to the abdomen by a movable flap, or dewlap, of very great size, extending far beyond the body, like a fin, and supported by branched flexible rays, resembling fin rays; side of tail often with a patch of spines, especially in the males. Vertebræ $7+11$ to $14=18$ to 21 . Species few, in warm seas, reaching a moderate size. All are lean fishes, with leathery skin, and bitter flesh unsuitable for flood.

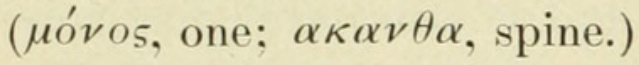

\section{MONACANTHUS CHINENSIS (Osbeck).}

Balistes chinensis Osвеск, Iter Chinensis, 1757, p. 147; China.-Bцoch, Ichthyol., II, 1787 , p. 29 , in later editions pl. LII, fig. 1; China.

Monacanthus chinensis, Cuvier, Règne Animal, 1st ed., p. 152, 1817 (name only).Bleeker, Atlas Ichth., V, 1865-69, p. 125, pl. ccxxiI, fig. 2.-Günther, Cat. Fish., VIII, 1870, p. 236; China, Pinang, Singapore, Shanghai.

Balistes sinensis Gmelin, Syst. Ichth., I, 1788, p. 1470 (after Bloch).

Monacanthus geographicus ("Péron"), Cuvier, Règne Animal, 2d ed., 1829, p. 373; Pinang.-Cantor, Malayan Fishes, 1850, p. 347; Pinang, Singapore.

Monacanthus cantoris BleEk ER, Nat. Tyds. Ned. Ind., III, 1852, p. 80 (after Cantor). Balistes granulosus Gronow, Syst., Ed. Gray, 1854, p. 34; Indian Seas.

Head $3 \frac{3}{4}$; depth 2 at origin of dorsal. D. I. 32; A. 31. Body compressed, deep, and covered with small scales; very rough. Head deep, the upper profile concave; snout produced upward, $1 \frac{1}{3}$ in head; eye high, small, $4 \frac{1}{2}$ in head, $3 \frac{1}{2}$ in snout, $1 \frac{1}{4}$ in interorbital space, equal to space between its lower margin and upper edge of gill opening, and $1 \frac{1}{2}$ in the gill opening; mouth small, high, and level with the upper part of the gill opening; lips smooth, thick, and fleshy; teeth strong 
and very slightly emarginate; jaws subequal; interorbital space very high and rounded; gill opening below eye oblique, its lower end in advance of the base of the pectoral and with a narrow fleshy flap. Spinous dorsal over the eye and posterior, rough, moderately thick, and with a series of large antrorse spines on each side; its origin nearer the tip of the snout than the origin of the soft dorsal; back with a triangular elevation, the apex the origin of the soft dorsal, and the origin of the anal falls a little behind this and below; dorsal and anal with their middle rays elevated; caudal deep, the middle rays long and the edge rounded; pectoral short and bluntly rounded, and equal to space between the lower margin of the eye and the lower edge of gill opening; ventral spine rough, a small spine on each side at base, movable, and a little longer than the eyes; abdomen behind ventral spine, between it and anus, developed into a long flap extending out from the body, beyond the ventral spine as far as the anal rays do themselves, and supported by very numerous, long, slender, cartilaginous stays resembling fin rays. Lower ventral region very. roughly striated toward the ventral fin on each side; caudal peduncle very rough, the tubercles enlarged and less numerous posteriorly, where there are two series of large spines curved outward and forward with 3 in each series.

Color of the body brown; 4 dark bars across the dorsal spine; soft dorsal with several narrow, wavy, longitudinal, blackish bars, the marginal portion with many small round light spots; anal with series of narrow, wavy, longitudinal, blackish bars, forming a network on the outer portion of the fin; caudal with many narrow blackish vertical bars over 3 dark bars, the outermost the darkest; pectoral plain; sides at the ventral region and at the base of the ventral fin blackish, the flap itself marked with narrow, wavy, blackish, netted bars. Total length $10_{\frac{5}{16}}$ inches. Our description is from a specimen obtained for us at Hongkong by Capt. William Finch, of the steamer Gaelic.

This species, very common on the coast of China from north China to Singapore, occurs in the Riukiu Islands and perhaps also in Japan. It is well figured in Bleeker's Atlas.

\section{STEPHANOLEPIS Gill.}

Stephanolepis Gild, Proc. Ac. Nat. Sci. Phila., 1861, p. 78 (setifer).

This genus, which includes the larger number of species of Monacanthidx, differs from Monacanthus in the little extension of the ventral flap, which does not form a dewlap and extends little beyond the ventral spine even in the adult. The surface of the flap is rough, with modified scales, but internal rays do not appear without dissection. Caudal peduncle usually without spines. The species are found in the warmer waters of both Asia and America.

( $\sigma \tau \varepsilon^{\prime} \phi \alpha v o s$, crown; $\lambda \varepsilon \pi i s$, scale.) 
a. Body comparatively deep, the depth in the adult about $1 \frac{3}{4}$ in the length.

$b$. Dorsal and anal rays about 34 ; dorsal fin in adult with the second soft ray much produced; none of the caudal rays produced; sides with several rather faint horizontal interrupted dark bars........................ cirrhifer, 10 .

$b b$. Dorsal rays 27 or 28 ; depth $1 \frac{5}{6}$ in length; scales very rough; no cirri on the fins; color, clouded brown .................................. japonicus, 11 .

aa. Body elongate, the depth about $2 \frac{1}{4}$ in the length; soft dorsal and anal high, of about 26 rays; one or more of the caudal rays produced in long filaments; color, mottled brown....................................

\section{IO. STEPHANOLEPIS CIRRHIFER (Schlegel).}

\section{KAWAHAGI (SKIN SCRAPER), MAHAGI (TRUE SCRAPER), KAWAMUKI} (SKIN PEELER); TOKOSE; CHUKO; TSANOKE.

? ? Monacanthus setifer Bennett, Proc. Comm. Zool. Soc., 1830, p. 112.

Monacanthus setifer Günther, Cat. Fish., VIII, 1870, p. 239; in part Japan, China, Zanzibar.-Nystrom, Sven. Vet. Handl., 1887, p. 47; Nagasaki.Ishikawa, Prel. Cat., 1897, p. 3; Boshu, Misaki; not of Bennett.

Monacanthus cirrhifer Schlegel, Fauna Japonica, 1846, p. 2@0, pl. cxxx, fig. 1; Nagasaki.-Bleek ER, Act. Soc. Sci. Indo-Nederl., III, 1857, Japan, IV, p. 31.-Steindachner, Reise Aurora, 1898, p. 223; Kobe.-Jordan and Snyder, Check List. 1901, p. 93; Yokohama.

Monacanthus komuki Bleeker, Verh. Ak. Wet., I, 1853, p. 13, fig. 1; Kaminoseki, D. I. 32; A. 31.-Bleeker, Act. Soc. Sci. Indo-Nederl., III, 1857, Japan, IV, p. 31; Kaminoseki.

Head $3 \frac{2}{5}$; depth $1 \frac{2}{3}$ to $1 \frac{4}{5}$; D. I. 34 ; A. 33. Body deep, strongly compressed. Head much deeper than long; snout produced, and the upper profile. line concave; lips thick and fleshy; edges of snout smooth; teeth powerful, the edges emarginate; upper jaw projecting when the mouth is closed; eye high up, 4 in head, 1 in space between its lower margin and gill opening, 3 in snout and 4 in interorbital space; gill opening as long as its distance from eye above, and with a fleshy flap; spinous dorsal directly behind eye, and much nearer soft dorsal than tip of snout; spine roughened on front, not thick, and with a series of antrorse barbs along the sides; its length varying from one-half to twothirds the space between its base and first soft dorsal ray. Soft dorsal higher than anal and caudal peduncle, and with its anterior rays the highest; caudal rays strong, the edge of fin convex but exceeding the caudal peduncle. Ventral spine small, roughened, and movable. Body smooth, but roughened between the ventral spine and the anus.

Color in spirits brownish; dorsal spine with four dark-brown bars; bases of soft dorsal and anal dark brown; the edges of the fins paler; caudal pale brown, with a terminal and median dark-brown bars; on sides many indistinct longitudinal bars of dark brown and on head and belly numerous small, indistinct brownish spots. Here described from specimens from Nagasaki, the largest reaching $10 \frac{1}{4}$ inches.

In young examples the markings on the sides are more distinct; and a dark spot is mostly evident on the upper side of the back; the gill opening shorter than the eye; dorsal spine robust. In oniy 3 
specimens is the second dorsal prolonged into a filament, 2 of them being from Misaki, the other from Hakata.

This fish is very common in shallow sandy bays in southern Japan. In color and form it approaches very closely to the Atlantic species, Stephanolepis hispidus, which Dr. Günther considers a "variety" of the same species. Steindachner claims that the Japanese species, Monacanthus cirrhifer, is distinct from the East Indian, Monacanthus setifer Bennett. The upper line of the head (in $M$. cirrhifer) is steeper, and the snout less projecting, and the dorsal spine shorter than in $M$. setifer. Our many specimens are from Tokyo, Misaki, Totomi Bay, Onomichi, Wakanoura, Kobe, Tsuruga, Hakata, and Nagasaki.

The species has many names in Japan, the commonest, Kawahagi and Kawamuki (wrongly spelled Komuki by Bleeker), meaning a fish which must have its skin peeled or scraped off before eating. Most of these names are also loosely applied to other Monacanthidæ, Balistidæ, and Acanthuridx. The present one is called Mahagi, the true skinscraper.

(cirrhifer, bearing fringes of hair.)

\section{STEPHANOLEPIS JAPONICUS (Tilesius).}

YOSOGI.

Monacanthus japonicus ${ }^{1}$ Tilesius, Mém. Soc. Moscou, II, 1801, pl. xirI; Japan (D. I. 24, A. 24).

Monacanthus trachyderma Bleeker, Act. Soc. Sci. Indo-Neerl., VIII, 1860; Japan, VI, p. 70; Nagasaki.-Günthen, Cat. Fish., VIII, 1870, p. 229.

Head, $2 \frac{1}{6}$ to $2 \frac{1}{3}$; depth, $1 \frac{5}{6}$; D. I. 27 and 28 ; A. 28 . Body oblong, deep, compressed, covered with rather large asperities, so that it is very rough to the touch. Head deeper than long, the upper profile nearly straight or very little concave; snout slightly produced; teeth strong, emarginate; lips rather thin, fleshy, and smooth; eye high in head, $2 \frac{2}{5}$ in snout and $3 \frac{1}{3}$ in head; interorbital space strongly convex. Gill opening below the posterior part of eye, a little longer than the space between the lower margin of the eye and its own upper extremity, with a narrow fleshy flap; spinous dorsal over posterior part of eye and midway between tip of snout and origin of soft dorsal; dorsal spine rather rough, and small antrorse spines in a single series laterally and posteriorly; origin of soft dorsal over that of anal, both of about

${ }^{1}$ We are indebted to Mr. Garman for the following copy of Tilesius's account of Balstes japonicus:

"Balistes jap., totus scaber, radio dorsali hispido postice aculeis recurvatis serrato, pinnis ventralis in unicam coalitis, hispidis coriaceis monacanthis, oculis maximis argenteo viridiscentibus, membrana nictitante tectis, apertura branchiali simplici, maxilla superiore prominente pinna caudali ad latera inermi."

P. 10 , V. $\frac{1}{12}$, A. 24 , C. 20 , D. $\frac{1}{24}$. The figure shows a small ventral flap. Ventral spine apparently immovable. Sides with cloudings and streaks. Body deep, twofifths or more of total length. 
equal height, with their anterior rays the longest and the margins of the fins obtusely rounded; caudal convex, the edges blunt; pectoral equal to the rather thick caudal peduncle; ventral spine produced and movable.

Color in alcohol dull brown with darker mottlings; spinous dorsai crossed by three dark brownish bands, another before its base, and still another from eye to eye; on the trunk are dark blotches, one at the origin of dorsal, two along the base of the anal; with the exception mentioned, all the fins are plain except the caudal, which has three

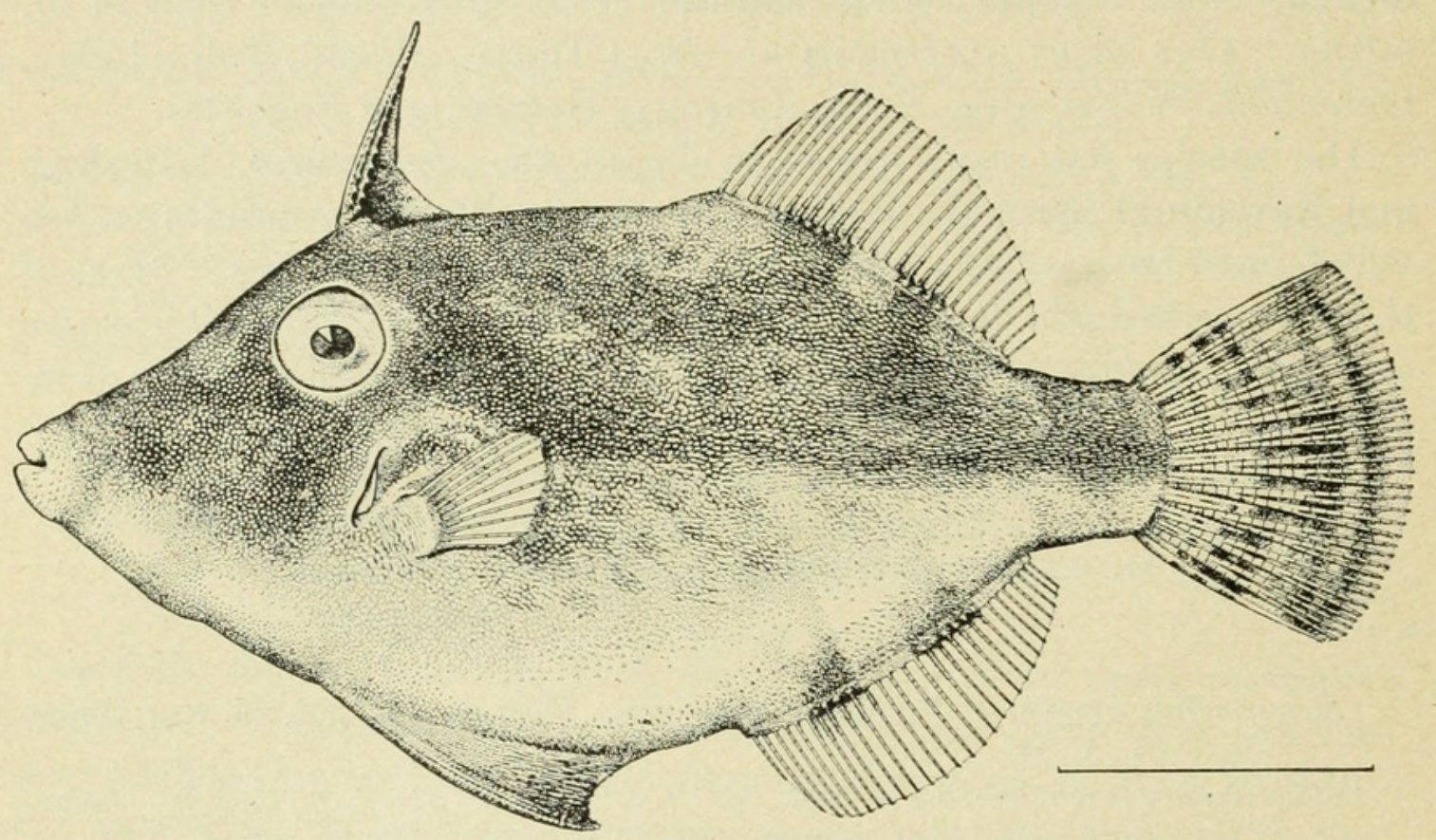

Fig, 1.-STEPHANOLEPIS JAPONICUS.

indistinct, broad dark bars, a brown ring around the snout, a bar across the throat below, and still another much farther below. The two specimens from which this description is taken were secured at Nagasaki, and measure $3 \frac{1}{16}$ and $4 \frac{3}{16}$ inches.

This species is known to us from two fine specimens taken at Nagasaki. It is well separated from Stephanolepis cirrhifer by the smaller number of fin rays, and by the rougher scales. It is probably not common.

\section{STEPHANOLEPIS OBLONGUS (Schlegel).}

\section{UMAZURAHAGI (HORSE-FACE SCRAPER).}

Monacanthus oblongus Schlegel, Fauna Japonica, Poiss., 1846, p. 291, pl. cxxx, fig. 2; Nagasaki (in part, figure and description of the young; two caudal filaments figured).-? Bleek ER, Act. Soc. Sci. Indo-Nederl., III, 1857, Japan, IV, p. 34, pl. III, fig. 1; Nagasaki (caudal figured with 4 upper, 4 median, and 2 lower filaments, 10 in all).-Günther, Cat. Fish., IV, 1862, p. 241; Japan, Zanzibar (?).

Monacanthus broeki Bleeker, Act. Soc. Sci. Indo-Nederl., III, 1857, Japan, IV, p. 35, fig. 2; Nagasaki (caudal figured with 1 upper and 1 median filament; eye $2 \frac{1}{2}$ in the long snout; dorsal spine short).

? Monacanthus frenatus Peters, Monatsb. Ak. Wiss., Berlin, 1855, p. 464. 
Head 3; depth $2 \frac{1}{4}$; D. I. 26; A. 27. Body oblong, compressed, and deepest anteriorly; skin fine velvety to the touch. Head deeper than long with the upper profile straight; snout not produced, blunt; eye high, 3 in snout, 1 in interorbital space, and 4 in head; interorbital space strongly convex; gill opening below the posterior part of the eye, level with the mouth, and greater than the space between its upper extremity and lower margin of eye; dorsal spine over the posterior part of the eye, finely striated, the sides with small antrorse spines behind, and its origin nearer the origin of the soft dorsal than the tip of the snout; soft dorsal and anal with their anterior rays very high, then rapidly diminishing in length till the last, which are very short, the lobe thus produced very blunt; caudal strong, its median rays the longest and forming a point, three of them ending in filaments, so that

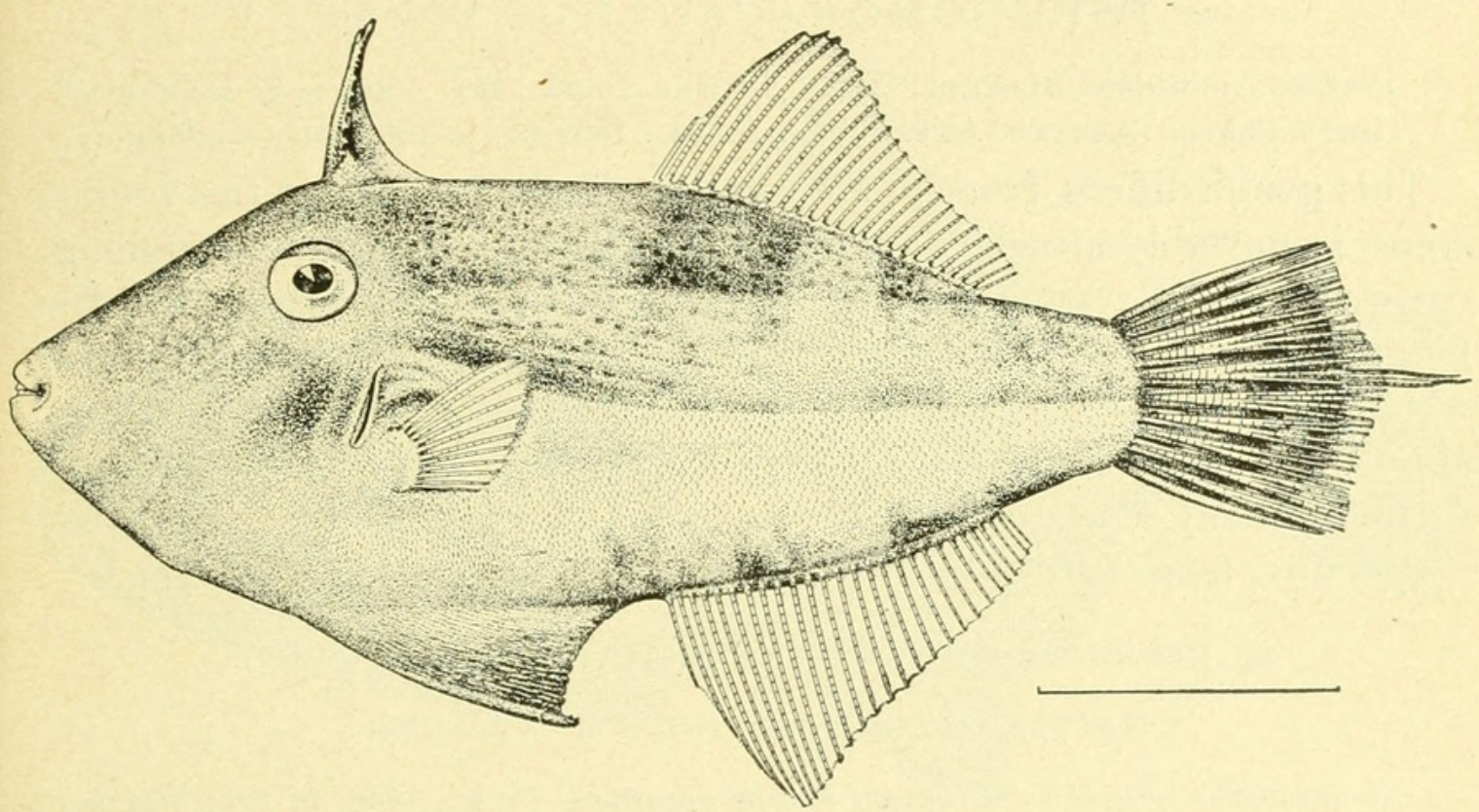

Fig. 2.-STEPHANOLEPIS OBLONGUS.

the upper and lower rays are the shortest; pectoral short, about equal to the deep, compressed caudal peduncle; ventral spine movable.

Color in alcohol brown marked with darker; a light streak from eye over gill opening on to the sides; several dark bars across dorsal spine, 1 at its base in front, and 1 from one eye to the other; traces of several dark bands across the throat; ventral region dark; 2 black spots on the back at the base of the dorsal, and 2 similar spots on the abdomen at the base of the anal; caudal brownish, with 3 indistinct cross-bars; membrane of spinous dorsal blackish; pectoral, ventral, and anal fins mostly plain; traces of several brownish bars across the throat. Here described from an example (with three caudal filaments) $4 \frac{1}{2}$ inches long, from Nagasaki.

This species is easily distinguished by its oblong form, filamentous caudal and high soft dorsal in connection with the movable ventral spine. It has been rarely taken about Nagasaki. We have a single 
specimen from that locality. This species is correctly described and roughly figured by Schlegel, who refers to it as the young of Monacanthus oblongus, regarding Pseudomonacanthus modestus as the adult of the same species. Schlegel's count of 5 rays (D-38; A-33) is evidently drawn from Pseudomonacanthus modestus. In the plates a much smaller number is shown. Our specimen corresponds to Schlegeil's figure of Monacanthus oblongus, and to the account of Monacanthus broeki given by Bleeker. Bleeker's oblongus, with 10 caudal filaments, higher dorsal spine, and shorter snout may be a different species, but it is probable that the difference is one of age or sex. No two of the recorded specimens agree as to the number of caudal filaments.

(oblongus, oblong.)

\section{PSEUDOMONACANTHUS Bleeker.}

Pseudomonacanthus Bleek er, Nedrl. Tydskr. Dierk., III. 1866, p. 11 (macrurus). Acanthaluteres BleEk ER, Atlas Ichth. Balist., 1865-69, p. 100 (paragaudatus).

This genus differs from Monacanthus chiefly in having the ventral spine immovably attached to the pelvic bone. The body is oblong, covered with velvety scales, the depth being not more than half the length. The dorsal spine has a row of retrorse barbs on each lateral edge, and usually a pair of rows of smaller barbs in front, the latter almost obsolete in old specimens. The species vary considerably in form. Chiefly East Indian.

$(\psi \varepsilon v \delta \eta \dot{s}$, false; Monacanthus).

\section{PSEUDOMONACANTHUS MODESTUS (Günther).}

\section{CHACHE; KUROHAGI (BLACK SCRAPER).}

Monacanthus oblongus Schlegel, Fauna Japonica, Poiss., 1846, p. 291; Nagasaki (in part, description of adults, not figures).

Monacanthus modestus Günther, Ann. Mag. Nat. Hist., 1877, p. 446; Inland Sea of Japan (D. II, 36; A., 34; depth, $2 \frac{3}{4}$ in length; dorsal spine broken, see Boulenger).

Pseudomonacanthus modestus Jordan and Snyder, Check List, 1901, p. 93; Yokohama, Hakodate.

Monacanthus poljakovi Henzenstein, Ann. Mus. Zool. Ac. St. Petersburg, 1896, p. 98; Yokohama, Coll. I. S. Poljakow. (Length $287 \mathrm{~mm}$., depth $2 \frac{2}{5}$ in length; D. II, 37; A., 35; adult specimen; profile convex.)

Monacanthus maximowiczii Herzenstern, Annuaire Mus. Zool. Ac. St. Petersburg, 1896, p. 9; Hakodate, Coll. Maximowicz. (Length $144 \mathrm{~mm}$., depth $2 \frac{1}{4}$ in length; D. II, 37; A., 35; young example; profile concave).

Monacanthus? ayraudi Ishik Aw A, Prel. Cat., 1897, p. 3; Boshu (not of Quoy and Gaimard).

Head $3 \frac{2}{5}$ to $3 \frac{3}{5}$; depth $2 \frac{1}{5}$ to $2 \frac{3}{4}$; D. I. 36 to 38 ; A. 34 to 36 . Body elongate, strongly compressed. Head deeper than long; snout not produced much; upper profile mostly convex; lips not very thick and fleshy; median teeth of the mandible the largest and most powerful, and all with notched edges; jaws almost equal; eye high in head, 4 in 
snout, and 5 in head, greater than the space between its lower margin and the gill opening and a little less than $1 \frac{1}{2}$ in interorbital space; nostrils small, gill opening $\frac{3}{4}$ the pectoral or equal to the convex interorbital space; with fleshy flap; spinous dorsal over posterior part of eye; its origin from midway to a point a little nearer the tip of the snout than the origin of the soft dorsal; rather slender spine, little roughed on front, and with 2 median series of very small tubercles, and a single series of antrorse barbs on each side. Soft dorsal and anal with the anterior rays much the longest, those of the former often more than half of the head; caudal rays strong; the edge convex; ventral spine small and rough; body smooth.

Color in spirits, pale brown, nearly uniform; the fins, deep vitriol blue, especially in the adult, outer portion of dorsal and anal darker than the base of the fin; caudal dark with the outer rays light. Here

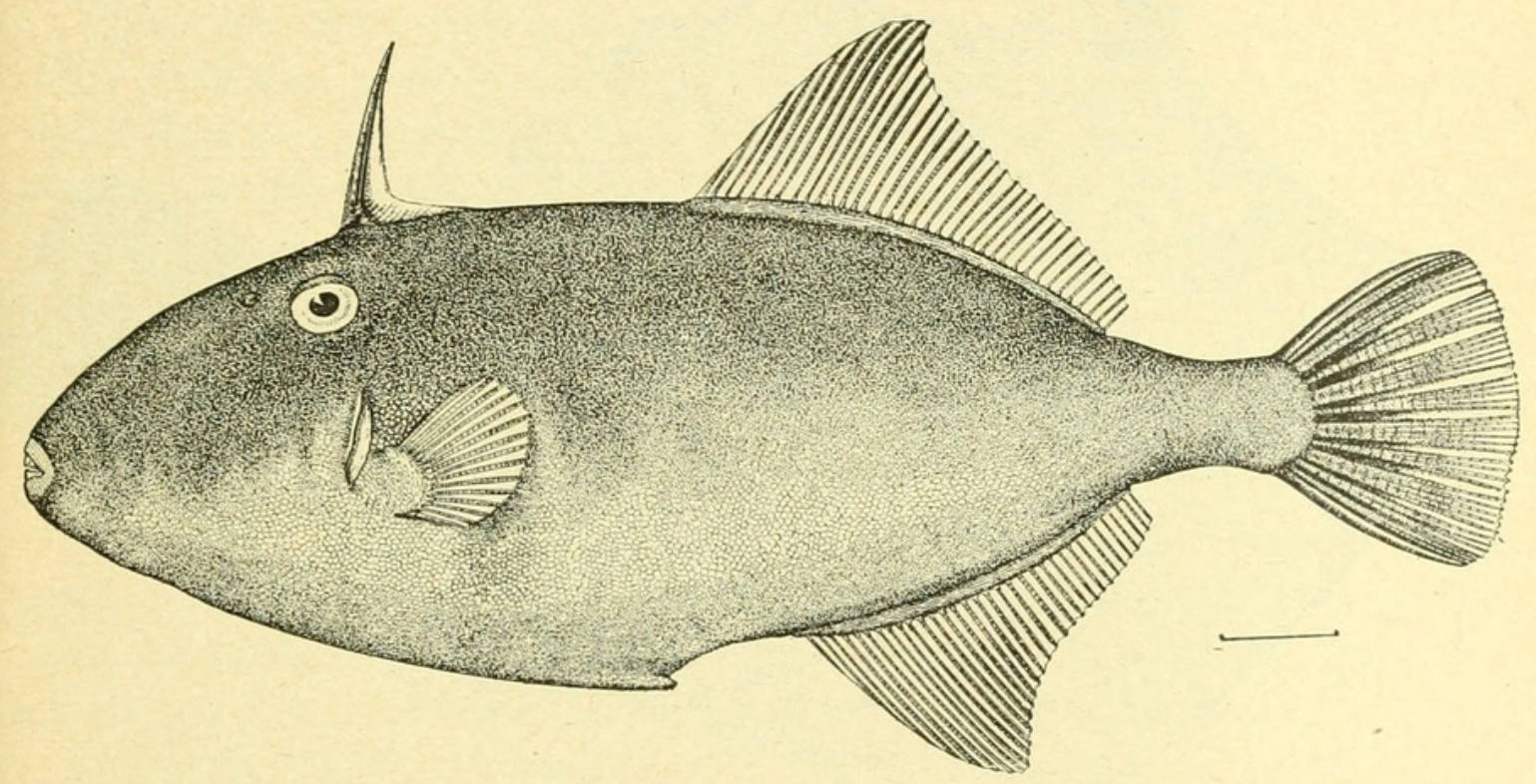

Fig. 3.-PSeudomonacanthus modestus.

described from specimens from Kobe, the largest $117 \frac{7}{8}$ inches long. In young specimens the color in spirits is pale brown, darker above, the sides with 5 dark brownish series of spots or blotches, and the caudal blackish on the outer portion with the outer rays light.

This species is very abundant on the coasts of Japan, reaching the length of a foot, and often coming into the markets when its flesh is regarded as wholesome. It is, in fact, the commonest and most widely diffused of all the Japanese filefishes, extending its range to the far north. In life the vitriol blue color of the fish serves to distinguish it. The dorsal spine is smoother and much more flattened in the adult than in the young, and there is considerable variation in depth of body with age or sex. Our many specimens are from Otaru, Hakodate, Aomori, Tokio, Misaki, Tsuruga, Kobe, Onomichi, Hiroshima, Hakata, and Nagasaki.

(modestus, modest.) 
10. RUDARIUS Jordan and Fowler.

Rudarius Jordan and Fowler, new genus (ercodes).

This genus has the immovable ventral spine of Pseudomonacanthus, with a short deep body, approaching that of Brachaluteres.

(rudis, rough).

14. RUDARIUS ERCODES Jordan and Fowler, new species.

Pseudomonacanthus trachyderma JoRDAN and SNYDER, Check list, 1901, p. 93; Yokohama (not of Bleeker).

Head 3 to $3 \frac{2}{5}$; depth $1 \frac{1}{4}$ to $1 \frac{1}{2}$; D. I. 25 or 26 ; A. 24 or 25 . Body short, deep and compressed; rather rough; the caudle peduncle some-

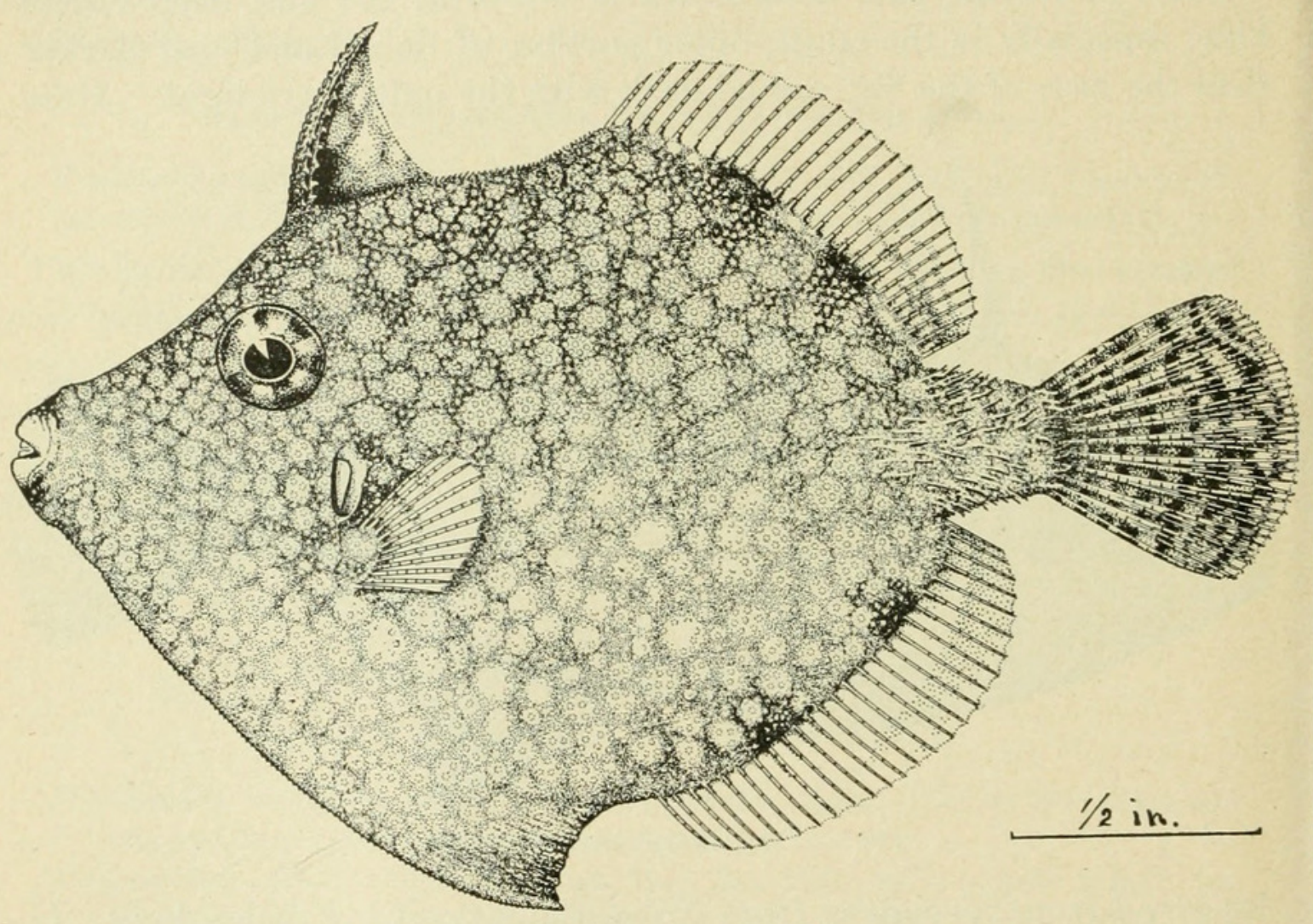

FIG. 4.-RUDARIUS ERCODES.

times with many slender curved spines. Head deep, its length about two-thirds its depth; eye rather large, superior, $1 \frac{2}{3}$ in snout, $2 \frac{2}{3}$ in head, equal to space between its lower margin and lower margin of gill opening; equal to caudal peduncle; interorbital space convex, greater than eye; upper profile concave; teeth emarginate, those in the lower jaw the larger; gill opening small, with narrow fleshy flap; lips moderately thick; jaws equal; spinous dorsal over posterior part of eye, convex, roughened in front; a single series of antrorse spines on each side, and its base midway or a little nearer the tip of the snout than the origin of the soft dorsal; soft dorsal and anal of nearly equal height; the origin of the latter a little in advance or under the origin of the former; caudal rounded; ventral spine short and rigid; pectoral equal or longer than the least depth of the caudal peduncle. 
Color in alcohol brownish; the lower part of the head and abdomen lighter; the membrane of spinous dorsal pale like those of the soft dorsal and anal, but marked with one or more blackish blotches; pectoral pale; caudal pale, base frequently darker and marked with about 6 narrow wavy blackish bars; often several ill-defined blackish patches on the sides of the body, 2 at the base of the soft dorsal, 2 above the base of the anal, and 1 above the anal spine; brown lines, darker than the ground-color, forming round light spots everywhere on the trunk, though varying in some examples; chin with black band from each corner of the mouth, extended downward in the middle; a dark stripe from chin to eye, then another a little below this, and finally still another further below; here described from specimen from Misaki; length $2 \frac{1}{2}$ inches. Little variation, except in depth of color, is to be found in our large series. Type No. 7127. Leland Stanford Junior University Museum.

This little fish, very different in appearance from Pseudomonacanthus modestus, may be recognized at once by its immovable ventral spine and its reticulated coloration. It is very common in the shallow bays of southern Japan. Our many specimens are from Tokio, Yokohama, Misaki, Tsuruga, Wakanoura, Onomichi, and Nagasaki.

( $\varepsilon^{\prime} \rho \kappa \circ$, a net; $\varepsilon \tilde{i} \delta \omega s$, resemblance.)

\section{BRACHALUTERES Bleeker.}

Brachaluteres Bleeker, Ned. Tyds. Dierk., III, 1866, p. 13 (trossulus).

Body very deep, almost circular, little compressed, covered with soft, velvety skin; no ventral spine; dorsal spine inserted above the eye; its surface rough with granules or bristles, but without barbs; fins short and low. Small fishes of the Australian and Japanese seas.

( $\beta \rho \alpha \chi v ́ s$, short; Aluteres.)

15. BRACHALUTERES ULVARUM Jordan and Snyder, new species.

Head $3 \frac{1}{5}$ to $3 \frac{2}{5}$; depth $1 \frac{2}{5}$ to $1 \frac{1}{2}$; D. I. 27 ; A. 25 . Body very deep, compressed, and fine velvety. Greatest depth of head twice its length; upper profile of the head slightly concave, the snout protruding a little; eye rather high in head, 2 in snout, $2 \frac{4}{5}$ in head and distant from the lower edge of gill opening about twice its own diameter; interorbital space convex; mouth small, high in head; lips not very thick; teeth emarginate and pointed; the jaws subequal; pelvic profile very round and convex; gill opening small, half the diameter of the eye, nearly vertical, below the posterior part of the eye and entirely above the pectoral, and with narrow fleshy flap; base of spinous dorsal nearer the origin of the soft dorsal than the tip of the snout; spine short, moderately thick, and finely roughened in front; soft dorsal and anal low, and the origin of the latter a little behind or under that of the former; caudal equal to the head or a little shorter, and its margin 
convex; pectoral short, rounded, and $1 \frac{1}{2}$ in snout; caudal peduncle rather thick and deep, $1 \frac{4}{5}$ to $2 \frac{1}{3}$ in head; its sides in the larger examples covered with numerous fine slightly recurved bristle-like spines.

Color plain brownish, 2 narrow dark bars across forehead from one eye to the other; fins all plain except the dark blotch on the membrane of the spinous dorsal above, and the caudal, which is washed with darker at the base, and with about 12 blackish wavy bars, broad basally; on the sides of the body are a number of fine narrow dark bars running longitudinally; indistinct traces of 2 dark blotches along base of soft dorsal and base of anal on the body; a narrow dark stripe

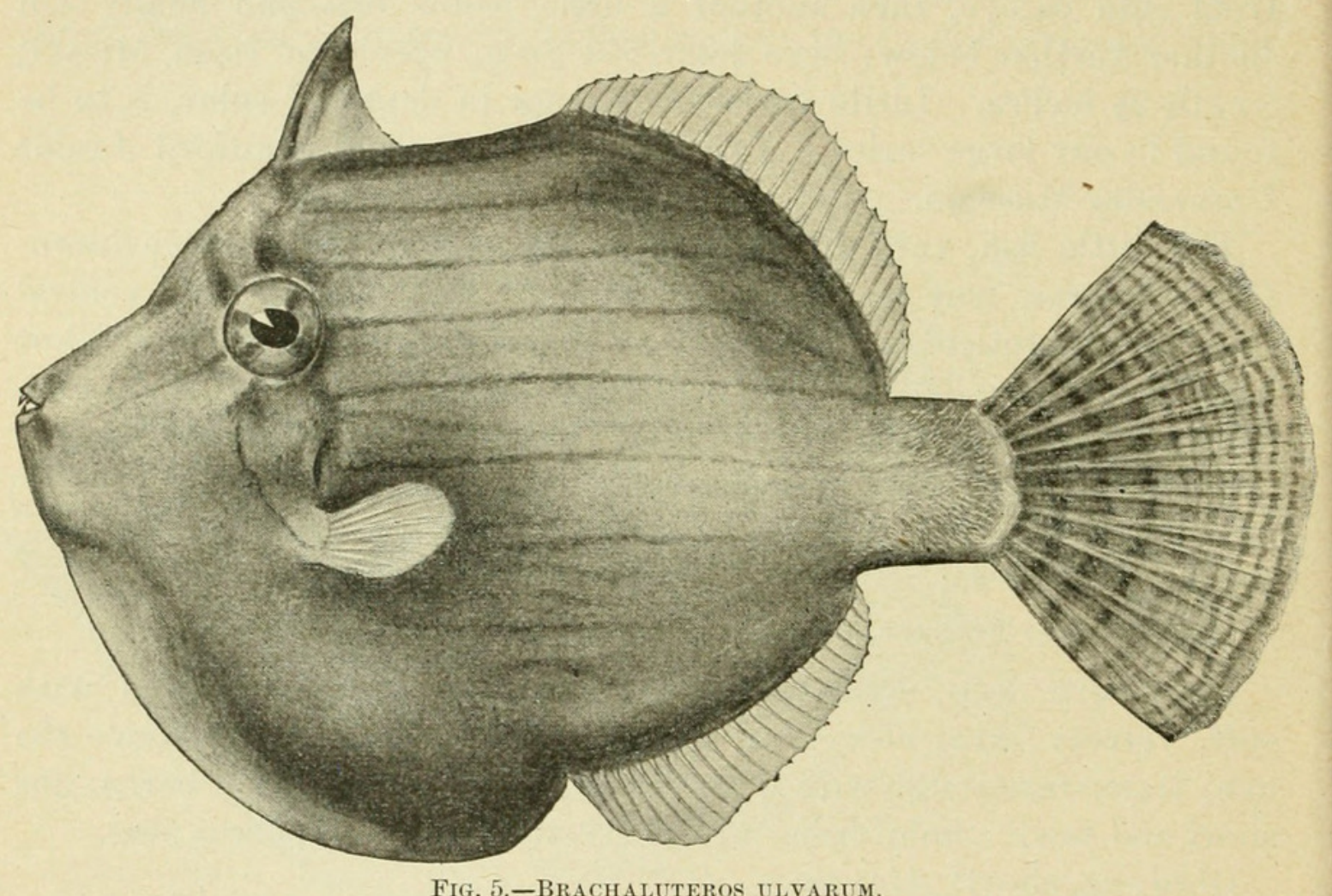

from eye down the sides of the snout, and another from the eye below convexly to the base of the pectoral. Here described from 2 examples from Misaki, $2 \frac{3}{8}$ and $2 \frac{7}{8}$ inches long. These are No. 7128. Leland Stanford Junior University Museum.

The species has been seen only in the bays around Misaki on the bottom of green sea weeds, where numerous specimens were taken.

(ulva, sea lettuce).

\section{PARALUTERES Bleeker.}

Paraluteres Bleeker, Atlas Ichth., V. 1865-69, p. 138 (prionurus).

Body considerabiy longer than deep, not greatly compressed, covered with finely granular skin; sides of tail with fine bristles and two pairs of spines pointing forward; no ventral spine; dorsal spine moderate, curved, covered with smooth skin, inserted behind the eye and bound down by the integument so as not to be fully erectile.

One species, small in size and handsomely colored.

( $\pi \alpha \rho \alpha$, near; Aluteres). 


\section{I6. PARALUTERES PRIONURUS Bleeker.}

Alutarius prionurus Bleek er, Verh. Bat. Gen., Balist., XXIV, 1852, p. 20, pl. III, fig. 6; East Indies.-Hollard, Ann. Sci. Nat., II, 1854, pl. xiv, fig. 10, and 1855, p. 21.

Paraluteres prionurus BleEker, Atlas Ichth., V, 1865-69, p. 138, pl. CcxxviI, fig. 1; East Indies, New Guinea.

Monacanthus prionurus GüNTHER, Cat. Fish., VIII, 1870, p. 234 (copied).

Head $3 \frac{1}{4}$; depth $1 \frac{4}{5}$; D. I. 26 ; A. 24. Body somewhat thick, compressed and smooth. Head deep, the snout not protruding much, so that the upper profile line is almost straight to the dorsal; eye high, 2 in snout, 3 in head, and $1 \frac{1}{2}$ in interorbital space; jaws equal; teeth pointed; lips rather thin and fleshy; interorbital space flat; gill opening 2 in interorbital space, nearly vertical; not far behind eye, and its distance

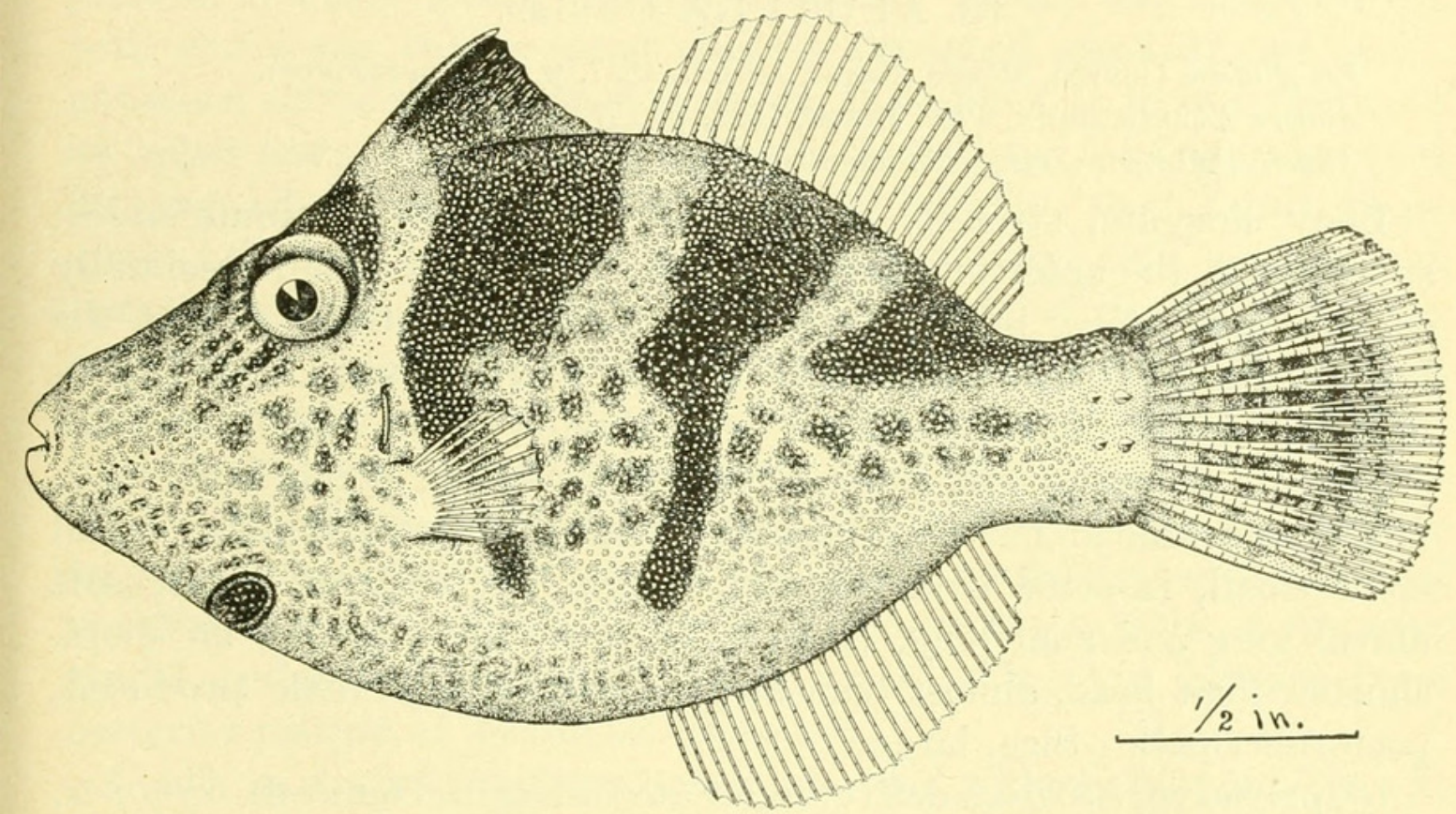

Fig. 6.-Paraluteres prionurus.

from the same much less its length; dorsal spine a trifle shorter than snout, covered with the skin of the back almost to its tip, its origin much nearer that of the soft dorsal than the tip of the snout, and falling over the posterior part of the eye; origin of soft dorsal a little before that of the anal, and the anterior rays of both fins the longer; longest dorsal rays longer than longest anal rays, and equal to the interorbital space; caudal rounded, the edges obtusely rounded; pectoral short, below the gill opening, and equal to the interorbital space. Caudal peduncle deeper than the length of the pectoral but not equal to the snout; posteriorly and on the sides a bare area in which 4 curved spines are placed in two series.

Color in spirits pale brownish, a band across base of spinous dorsal from eye to eye; 2 broader bands, both narrow, on the sides of the body until level with the eye, when they become broad, extend over the back, the first including the upper half of the spinous dorsal and

Proc. N. M. vol. $\mathrm{xxV}-02-18$ 
region between the two dorsals, and the other not extending on the soft dorsal at all, blackish brown; back blackish brown behind second dorsal band to the base of the upper caudal ray; on the throat a round black spot on each side; head and lower surface of the body marked with various brownish spots and blotches becoming large and few in number on the posterior sides of body; soft dorsal, anal, and pectoral fins plain; caudal plain except indistinct blackish lunate bar from base of upper rays to base of lower and marked with small whitish spots; length $2 \frac{5}{16}$ inches. Here described from Wakanoura, from the only specimen of this pretty and interesting little fish taken by us. It differs a little in color from Bleeker's figure, but it is probably the same species.

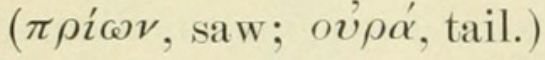

\section{Alutera Cuvier.}

Les Alutères Cuvier, Règne Anim., 1st ed., 1817, p. 153 (monoceros).

Alutera Agassiz, Spix, Pisc. Brasil, 1829, p. 137 (monoceros).

Aluteria, Aluterius, etc., corrected spelling.

Body elongate, strongly compressed, covered with minute scales; snout short, the anterior profile convex; mouth and teeth essentially as in Monacanthus, but the lower jaw more projecting, so that the lower teeth are directed obliquely upward and backward. Gill opening an oblique slit, longer than eye, situated below and in advance of eye, its posterior end behind base of pectorals; pelvic bone long, falcate, movable under the skin, without spine at its extremity; dorsal spine small, inserted over the eye, rough, but without barbs; soft dorsal long and anal long, each of 45 to 50 rays; caudal fin short, shorter than head, almost truncate, the middle rays little produced; pectorals small. Size, large.

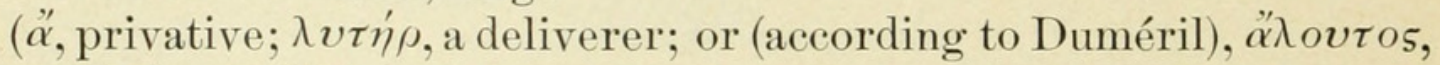
unwashed, sordid.)

\section{ALUTERA MONOCEROS (Osbeck).}

Capriscus murium dentibus minutis KleIn, Ichth. Missus, III, p. 25, 1742, pl. III, fig. 9; very bad, no locality.

Balistes monoceros Osвeck, Iter Chinensis, 1757, p. 110; China.-Lrnneus, Syst. Nat., 10th ed., I, 1758, p. 327 (after Osbeck).

Balistes oblongiusculus, etc., Gronow, Zoophyl., 1765, No. 193; Indian seas.

?Lija barbuda PArra, Dis. Piezas Hist. Nat., 1787, p. 48, pl. xxII, fig. 2; Habana. Balistes kleinii Gmelin, Syst. Nat., 1788; Indian seas (after Gronow and Klein). Balistes barbatus Walbaum, Artedi Piscium, III, 1792, p. 464 (after Klein).

Balistes monoceros var. unicolor BLOCH and SchneIder, Syst. Ichth., 1801, p. 463 (after Gmelin).

Balistes serraticornis Fréminville, Nouv. Bull. Se. Soc. Philom., No. 67, 1813, p. 249 , pl. Iv, fig. 1.

Aluteres berardi Lesson, Voyage Coquille, Zool., 1828, p. 108, pl. vir; New Guinea. Alutera cinerea Schlegel, Fauna Japon., Poiss., 1846, p. 292, pl. cxxxI, fig. 1; Nagasaki.

Alutarius amphacanthus Bleeker, Verh. Bat. Gen., Balist., XXIV, p. 23, pl. II, fig. 5; East Indies. 
Alutarius obliteratus Cantor, Malayan Fishes, 1850, p. 353; Pinang.

Balistes linguatula Gronow, Cat., Ed. Gray, 1854, p. 35; Indian seas (after Balistes oblongiusculus, etc., of Gronow).

Aluterus anginosus Hollard, Ann. Sci. Nat., IV, 1855, p. 11; East Indies.

Balistes unicornus Basilewsky, Nouv. Mém. Soc. Nat. Moscou, X, 1855, p. 263; North China.

Alutarius macracanthus Bleeker, Verh. Bat. Gen., XXIV, 1852, Balist., p. 22, pl. III, fig. 6; East Indies.

?Alutera guntheriana Poex, Proc. Ac. Nat. Sci. Phila., 1863, p. 184; Habana.

Monocanthus monoceros GüNTHer, Cat. Fish., VIII, 1870, p. 251; Zanzibar, Pinang, Amboyna, China, Japan.-Nystrom, Svensk. Vet. Handl., 1887, p. 47; Nagasaki.

Alutera monoceros Jordan and Evermann, Fish. N. and M. Amer., II, 1898, p. 1720.

Head $3 \frac{3}{5}$; depth $2 \frac{2}{5}$; D. I. 49; A. 51. Body oblong, much compressed, and skin with a fine velvety touch. Head very deep, convex both above and below; snout slightly produced upward; eye small, not much above the mouth, 5 in snout, $5 \frac{2}{3}$ in head, $1 \frac{2}{3}$ in space between its upper margin and origin of spinous dorsal, and 1 in space between its lower margin and upper margin of gill opening; teeth broad, emarginate, the middle mandibular pair pointed; lips thin and narrow, smooth; nostrils small, in front of upper part of eye; gill opening rather long, oblique forward till a little anterior to the nostrils, $2 \frac{2}{3}$ in snout and equal to pectoral; origin of spinous dorsal over the anterior edge of eye, and midway between the tip of the snout and the origin of the soft dorsal; soft dorsal and anal with the anterior rays the longer, the longest in both of the fins equal; caudal damaged; pectoral inserted below the mouth and a little behind the middle of the eye; caudal peduncle compressed, equal to one-third the distance from posterior margin of eye to tip of snout.

Color, in alcohol, uniform brown, mottled with darker, and the fins all plain-colored and pale. Here described from a specimen $10 \frac{1}{4}$ inches long, obtained by Professor Otaki in the market at Tokyo. Tropical seas, ranging widely, recorded from Cape Cod, throughout the East and West Indies, and from Nagasaki in Japan, where it must be rare. The original Alutera monoceros came from China. The American species, Alutera guntheriana Poey, will very likely prove different.

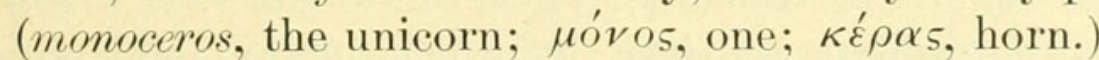

14. OSBECKIA Jordan and Evermann.

Osbeckia Jordan and Evermann, Check List Fishes N. A., 1896, p. 424 (scripta).

This genus is very close to Alutera, differing in the longer snout, concave anterior profile, and very long caudal fin, in which the outer rays are much shortened. Size large. From the American genus, Ceratacanthus, a very near relative, Osbeckia differs in the longer dorsal and anal fins, there being about 36 rays in Ceratacanthus.

(Named for Per Osbeck, a pupil of Linnæus and an excellent naturalist, who explored the coasts of China about 1750.) 


\section{OSBECKIA SCRIPTA (Osbeck).}

Unicornu pisces bahamensis (the Unicorn fish) Catessy, Hist. Nat. Carolina, etc., II, 1737, pl. xIx; Bahamas.

Balistes scriptus Osвеск, Iter Chin., I, 1757, p. 144; China.

Balistes monoceros, var. scriptus Gmelin, Sys. Nat., 1788, p. 1463 (after Osbeck). Monacanthus scriptus GüNTHER, Cat., VIII, 1870, p. 252.

Alutera scripta Jordan and Evermann, Fish. N. and M. Amer., III, 1898, p. 1719.

? Lija trompa Parra, Dis. Piezas Hist. Nat., 1787, p. 46, pl. xxII, fig. 1; Habana.

Balistes loevis BLoch, Ichthyol., IX, 1795, p. 82, pl. ccccxIv; Moroceo, Tranquebar.

Balistes ornatus Marion de Procé, Bull. Soc. Philom., 1822, p. 131; East Indies. Aluteres pareva Lesson, Voy. Coquille, Zoöl., 1824, p. 106; East Indies.

? Monacanthus proboscideus Ranzani, Nov. Comm. Ac. Sc. Inst. Bonon., 1842, p. 8; Brazil.

Aluterus venosus Hollard, Ann. Sc. Nat., 4th ser., IV, 1855, p. 14, pl. I, fig. 3;

New Ireland, Bismarck Archipelago. Coll. Lesson and Garnot.

? Alutera picturata Poey, Proc. Ac. Nat. Sci. Phila, 1863, p. 183, Cuba.

Head 3; depth $3 \frac{1}{5}$; D. I. 44 to 46 ; A. 46 to 48 . Body oblong, greatly compressed, the depth a little greater than the space between the tip of the snout and the posterior margin of the eye. Head long, its depth equal to space from tip of snout to posterior margin of eye; snout produced upward, the upper profile concave; eye rather small, $3 \frac{1}{2}$ to $4 \frac{1}{2}$ in snout, 4 to $5 \frac{1}{4}$ in head, $\frac{3}{5}$ equal to its diameter to 1 in the space between the upper end of the gill opening and its lower margin, and equal to interorbital space; mouth small; jaws subequal; teeth pointed; lips thin and rather narrow; gill opening beginning before the eye, but not as far forward as the nostril, runs obliquely upward until below the origin of the spinous dorsal. Spinous dorsal over back part of the eye and nearer the tip of snout than the origin of the soft dorsal or else midway between; pectoral inserted level with the anterior margin of the eye, or a little in front of its center, and in the middle of the space between its lower margin and the lower edge of the body; dorsal and anal fins low, the anterior rays of both a little longer than the others, and their origins opposite; caudal long, very long in young, in which it is $2 \frac{1}{4}$ in body, and with the median rays much longer than the others; caudal peduncle 2 or a trifle over in head.

Color of young in spirits uniform brownish, many light-biuish curved streaks and spots, some nearly as large as the pupil of the eye; fins, except the caudal, all plain-colored, caudal fin barred with broad, irregular dark-brownish stripes on its basal portion, and with its outer part dark-brownish. Skin fine velvety. Tropical seas, common in East and West Indies alike, occasionally met with on the west coast of Mexico, rare northward. We have received a single small specimen, $5 \frac{3}{8}$ inches long, from Kiusiu from Professor Mitsukuri, and a stuffed one, $13 \frac{5}{8}$ inches long, from Nagasaki from a local collector. The above description is from these two specimens. 
Alutera scripta is probably rare in Japan. The original scripte came from China; the American species, Osbeckia proboscidea Ranzani, may very likely prove to be different.

(scriptus, written, from the form of the markings.)

\section{PSEUDALUTERES Bleeker.}

Pseudaluteres Bleek er, Ned. Tyds. Dierk., III, 1865, p. 28 (nasicornis).

This genus differs from Osbeckia in the small size and anterior insertion of the dorsal spine, which is weak and placed in advance of the orbit.

$(\psi \varepsilon v \delta \dot{\eta} s$, false; Alutera).

\section{PSEUdaluteres NASICORNIS (Schlegel).}

Alutera nasicornis Schlegel, Fauna Japonica, Poiss., 1846, p. 223, pl. cxxxi, fig. 2; Nagasaki.-Bleeker, Nat. Tyds. Ned. Ind., V, 1853, p. 352.

Pseudoluteres nasicornis Bleeker, Ned. Tyds. Dierk., III, 1865, p. 28.-Bleeker, Atlas Ichth., V, 1865-69, p. 139, pl. ccxxi, fig. 1; pl. cCXXIv, fig. 2.

Monacanthus nasicornis GÜNTHER, Cat. Fish., VIII, 1870, p. 254; Zanzibar, Amboina.

Aluterus rhinocerus Hollard, Ann. Sci., IV, 1855, p. 19, pl. I, fig. 5.

Depth 3 in length; D. II. 43 to 49 ; A. 41 to 46 . Body oblong, covered with minute rough scales. Snout convex in young males and very convex in adult males; eye $3 \frac{2}{3}$ to 4 in head, and $2 \frac{1}{2}$ in snout; teeth sharply compressed; the lower emarginate; gill opening arising before the middle of the base of the pectoral, and below the posterior part of the orbit; spinous dorsal before the eye and nostrils, nearly as long as the head, straight and without barbs; soft dorsal and anal low, obtusely rounded, with the origin of the former in advance of the latter; caudal shortly rounded but with the angles acute; pectorals obtusely rounded. Color yellowish or reddish brown; a broad stripe from eye to caudal, like the back, olive or brownish violet; rays of fins yellow or golden, the membranes clear bluish; middle of caudal purplish-blue or brown; eyes yellow; males with 2 narrow bluish bars on sides, the upper through the eye and parallel with the dorsal outline of the back to the base of the last dorsal ray, and the lower from along the abdominal region; body everywhere with small red spots, which run in a series along the bases of soft dorsal and anal. Length $5 \frac{1}{2}$ inches. (Schlegel, Bleeker, Günther.)

This little fish, not rare in the East Indies, has been but once recorded from Japan. It was not taken by us.

(nasus, nose; cornu, horn.) 


\section{Suborder OSTRACODERMI. ${ }^{1}$}

This group includes those Plectognaths which are without spinous dorsal and which have the body inclosed in a 3-angled, 4-angled, or 5angled box or carapace, formed by polygonal, bony scutes, firmly joined at their edges, and with distinct teeth in the jaws. There is but one family, the Ostraciidx, a singular offshoot from the Sclerodermi.

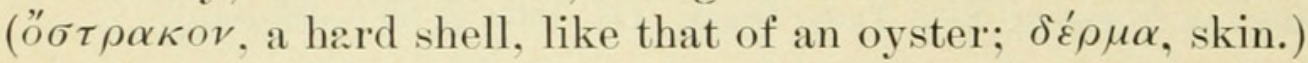

\section{Family IV. OSTRACIIDA.}

\section{TRUNK FISHES.}

Body short, cuboid, triquetrous or pentagonal, covered by a carapace formed of firmly united polygonal bony plates, the jaws, bases of the fins, and caudal peduncle free and covered by smooth skin. Mouth small; each jaw with a single series of long, narrow teeth. Maxillaries and premaxillaries firmly united. Gill opening a nearly vertical slit, below and behind the eye. Dorsal fin single, short, without spine; anal short, similar to dorsal; caudal rounded; no ventral fins; vertebræ 14 , the anterior 9 elongate, the last 5 extremely short; no ribs. All are species of the tropical seas, living near the bottom in shallow waters. The species of this group are so singular in appearance and so easily preserved that they have been common in collections ever since the gathering of tropical curiosities began.

a. Carapace forming a continuous bridge behind the anal fin; ventral surface not carinate; caudal rays 10.

b. Body 4-angled, sometimes with an additional median dorsal spine.. Ostracion, 16 aa. Carapace open below behind the anal fin; carapace 6-ridged, a ridge along the middle of each side ...................................... 17

\section{OSTRACION Linnæus.}

Ostracion Linn æus, Syst. Nat., 10th ed., 1758; p. 330 (many species; first restricted by Swainson to 4-angled forms, cubicus taken as type).

Tetrosomus Swarnson, Classn. Fish., II, 1839, p. 323 (turritus).

Cibotion Kaup, Wiegmann's Archiv. Natur., 1855, p. 214 (cubicus).

Lactoria JoRDAN and Fowler, new subgenus (cornutus).

Trunk fishes with the carapace closed behind the anal fin; carapace with or without frontal and abdominal spines; dorsal rays 9 or 10 ; caudal rays always 10 ; lateral ridges developed; median dorsal ridge undeveloped or else raised with a sharp spine, and the body is therefore 4-angled or 5-angled. Although this character is a striking one, it is not one of high structural importance. Hollard and Bleeker have discarded it as being of no real systematic value. We think, with Dr. Goode, that the shape of the carapace affords " the most reliable

${ }^{1}$ This name should be used for the trunk fishes, and not for the Ostracophori or extinct mailed allies of Pterichthys, for which it has been so frequently taken. 
guide in the arrangement of the species of the genus," and we find it difficult to define more than two genera in the family, unless we assign generic rank to each of the leading sections. In Japan three of these sections are represented, Tetrosomus, Lactoria, and Ostracion. The remaining four, Rhinesomus, Chapinus, Lactophrys, and Acanthostracion, are all based on the 3-angled species, a type confined to the West Indian Region, and by Jordan and Evermann taken as a distinct genus, Lactophrys. This division into 3-angled American species, Lactophrys, and 4-angled Asiatic species Ostracion, is here accepted.

a. Tetrosomus. Carapace 5-angled, the dorsal ridge surmounted by a very high spine; plates of sides with dark spots . . . . . . . . . . . . . . . . . . gibbosum, 20 aa. Carapace 4-angled; the back without conspicuous central ridge and with a small spine or none, carapace closed behind the dorsal fin.

b. Ostracion. Carapace without spines anywhere; plates of sides with blue spots. immaculatum, 21

bb. Lactoria. Carapace with spines, one before each eye being conspicuous.

c. Frontal spines, short, divergent; center of back with a spine, a small spine opposite it on each lateral ridge; ventral ridge with a spine behind and usually two smaller ones before it; caudal fin moderate; plates somewhat translucent. . . . . . . . . . . . . . . . . . . . . . . . . . . . . . . . .

cc. Frontal spines very long, directed forwards; ventral ridge with a long spine behind; a low, blunt spine on back; caudal fin very long in the adult, with

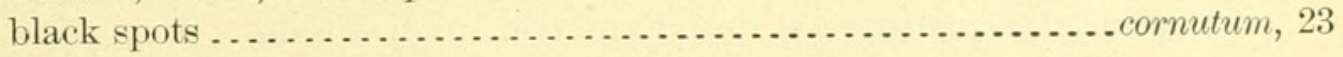

20. OSTRACION GIBBOSUM Linnæus.

Ostracion gibbosus Linnæus, Syst. Nat., 10th ed., 1758, p. 331; India (after Ostracion quadrangulus gibbosus of Artedi).-Günther, Cat. Fish., VIII, 1870, p. 258; Zanzibar, Persian Gulf, Borneo, India.

Ostracion turritus Forsk ̊l, Descr. Anim., 1775, p. 75; Red Sea.-Bleeker, Verh. Ak. Wet. I, 1853, p. 15; Kaminoseki, Inland Sea of Japan.-Blekker, Atlas Ichth., V, 1865-69, p. 31, pl. III, fig. 3; Java, Celebes, Buro, Amboina, Ceram.-Goode, Proc. U. S. Nat. Mus., 1879, p. 21, and of most authors.

Lactophrys camelinus DeкAy, New York, Fauna, Fishes, 1842, p. 341, pl. Lvin, fig. 190 (recorded by error from Long Island).

Head 3 ; depth $1 \frac{5}{6}$; D. 9 ; A. 9 ; P. 10 ; scales 9 from gill opening to end of carapace, 11 across widest part of carapace below, and 8 between spine on the back and outermost lateral spine. Eye 2 in head and $1 \frac{1}{5}$ in snout; snout obtuse, inferior, very little depressed above; interorbital space concave; mouth small, lips rather thick; teeth small and pointed; nostrils small and directly in front of eye; supraorbital ridge with a weil-developed spine. Carapace with 4 ridges, the upper 2 much closer together than the lower ones, along which are 2 low postocular and 4 low posterıor spines on each side; median ridge of the back forming a large, compressed, elevated, and triangular spine curving backward; ventral ridges furnished with 5 spines on each side curving backward, the first one of which is small; gill slit short, directly behind the eye; dorsal small, entirely in 
advance of the anal, and behind the large spine on the back; caudal, $3 \frac{1}{2}$ in the length of the carapace; pectoral large, equal to the snout, which is twice as long as the depth of the caudal peduncle.

Color in alcohol dull brownish, under surface of the carapace plain; sides of body with blackish blotches forming 5 indistinct bars obliquely directed backward; a blackish spot on spine of the back, base of dorsal, caudal peduncle, base of anal; and 2 blackish bars across caudal fin; interorbital region and tip of the snout dark. Length, $1_{1 \frac{9}{6}}$ inches. Here described from an example from Cavite, Philippine Isiands.

This common East Indian species has been once recorded by Bleeker from Kaminoseki in the Inland Sea of Japan. It may be known at once by the hump-like spine on the back. It was not seen by us in Japan.

(gibbosus, gibbous.)

\section{OSTRACION IMMACULATUM Schlegel.}

\section{GINHAGI (SILVER SCRAPER); HAKO FUGU (BOX PUFFER).}

Ostracion immaculatus Schlegel, Fauna Japonica, Poiss., 1846, p. 296; Nagasaki.Bleeker, Nalez, Ichth. Japan, 1853, p. 55; Nagasaki.-Brevoort, Exped. Japan, 1856, p. 284; Shimoda.

Ostracion cubicus Isnikawa, Prel. Cat., 1897, p. 3; Misaki.

Head 4; depth $2 \frac{4}{5}$; D. 9; A. 9; scales 11 from gill opening to end of carapace, 9 across widest part of ventral region, 7 across widest part of dorsal region, and 7 across widest part of lateral region. Head small; profile in front steep; snout protruding, concave above; mouth low, level with base of pectoral, subinferior; eye high, 3 in head, 2 in snout, and 2 in interorbital space; lips thick and fleshy; teeth rather small and pointed; interorbital space concave; nostrils small. Gill-slit behind eye, in front of pectoral, obliqueiy vertical, about 2 in head, and with narrow fleshy flap; carapace 4-angled, the edges rounded, and without any spines. Dorsal aitogether in advance of the anal, and a trifle higher; caudal long, obtuseiy convex, about 4 in carapace; pectorals long, equal to dorsal and inferior in position; scales of carapace mostiy hexagonal on sides; caudal peduncle rather thick, about equal to eye and gill opening.

Color in aicohol brownish, pale below and dark above, where most of the scales together with those of the sides show traces of a dark spot nearly as large as the pupil; snout dark; fins all plain, with their outermost portion dark; caudal peduncie brownish, darker above, and with traces of dark spots. In life olive with sky-blue spots on the scaies of the side. Length of longest exampie, $7_{16} \frac{7}{6}$ inches. Here lescribed from specimens from Hakata, and one from Nagasaki. The iargest specimen we have of this species is from Wakanoura, and is $8 \frac{3}{8}$ inches long.

This trunkfish is common in the bays washed by the Kuro Shiwo from 
Tokyo southward. Our numerous specimens are from Tokyo, Misaki, Aburatsubo (Sagami), Enoshima, Wakanoura, Hakata, and Nagasaki.

It is probably a subspecies of Ostracion tuberculatum ${ }^{1}$ (cubicum), as Bleeker has indicated, or even it may be the same species with it, as Günther regards it. We give it provisional rank as a distinct species because all our specimens are deeper in body than O. tuberculatum; none of them show any of the black spots characteristic of that species, and in our experience very few of the fishes permanently resident along the coast of Japan are exactiy identical with the cognate species of the East Indies. The absence of frontal and dorsal spines at once dis. tinguishes this from the other Japanese trunk-fishes.

(immaculatus, unspotted.)

22. OSTRACION DIAPHANUM Bloch and Schneider.

O. UMITSUZUME (BIG SEA SWALLOW); SUZUMEFUGU (SWALLOW PUFFER).

Ostracion diaphanus Bloch and Schnemer, Syst. Ichth., 1801, p. 501; no locality.-Bleek Er, Act. Soc. Sci. Indo-Nederl., III, 1857, Japan, IV, p. 38.Hollard, Ann. Sci. Nat., 1857, VIII, p. 157.-Günther, Cat. Fish., VIII, 1870, p. 264; Cape of Good Hope, Japan.-Ishikawa, Prel. Cat., 1897, p. 3; Kagoshma, Sagami (one specimen wrongly called O. fornasini).

Ostracion brevicornis Schlegel, Fauna Japonica, Poiss., 1846, p. 297, pl. cxxx, fig. 3; Nagasaki.

Ostracion undecimaculeatus Sмгтн, Ill. Zool. S. Afr., 1838-42, pl. xvin; Cape of Good Hope.

Ostracion pentacornis Bennetr, Whaling Voyage, 1839, p. 266.

Ostracion cornutus BleEker, Atlas Ichth., V, 1865-69, p. 33, pl. II, fig. 2; pl. IV, fig. 3, Amboyna, Nagasaki (not of Linnæus, according to Peters, Berlin, Monat. Ak. Wiss. Berlin, 1868, p. 461).

Head 4 ; depth $2 \frac{2}{5}$; D. 9 ; A. 9 ; scales 10 from gill opening to end of carapace, 12 across greatest ventral width, and 8 in a series from dorsal spine to ventral keel. Body moderately long, heavy forward, broader than deep, and convex below. Carapace with 4 ridges, the

${ }^{1}$ The following are the chief synonyms of Ostracion tuberculatum:

Ostracion tetragonus Linnfus, Mus. Adolph-Frederik, 1759, p. 59; India (date prior to 1758, the recognized beginning of binominal nomenclature).

Ostracion tuberculatus Linnaus, Syst. Nat., 10th ed., 1758, p. 331; India (after Artedi, p. 84; no species; back with 4 tubercles).

Ostracion cubicus Linneus, Syst. Nat., 10th ed., 1758, p. 331; India (after Ostracion tetragonus Günther, Cat. Fish., VIII, 1870, p. 260, and of authors generally).

Ostracion bituberculatus BLoch and ScHneIder, Syst. Ichth., 1801, p. 501; Pacific Ocean (after Lacépède).

Ostracion argus Rü Ppell, Atlas Fische, 1828, p. 4, pl. I, fig. 2; Red Sea.

Ostracion cyamurus Rüppelt, Atlas Fische, 1828, p. 4, pl. I, fig. 2; Red Sea.

Ostracion tesserula Bleeker, Nat. Tyds. Ned. Ind., III, 1852, p. 305; Molucca (not of Cantor).

Ostracion tetragonus BleEker, Atlas Ichth., V, 1865, p. 39, pl. III, fig. 2; Java, Sumatra, Singapore, Celebes, Amboyna, etc. 
greatest width of the dorsal fin equal to one-fourth the length of the carapace; a supraocular spine pointing forward and a small spine in the middle of the dorsal ridge on each side, and at the same point as the latter a large spine somewhat curved backward in the middle of the back; ventral ridges terminating in a strong spine, and on each side between its base and the base of the pectoral fin are 2 small spines at equal distances. Head deep, profile above steep, convex, and with snout projecting; mouth below gill opening small, with small pointed teeth; lips thick and fleshy; eye high, 2 in snout, $2 \frac{3}{5}$ in head, and $1 \frac{3}{5}$ in interorbital space; interorbital space concave; gill opening short, one-half in eye and posterior to it; base of the dorsal at the last fourth of the carapace higher than anal; origin of anal midway between base of last dorsal ray and end of carapace; caudal equal to space from origin of dorsal to end of carapace, the lower rays the longer, and its edge oblique; pectoral with upper rays the longest and equal to snout; caudal peduncle rather thick, 2 in snout.

Color in alcohol brownish, lighter below, and with many black spots all over the upper surface, small on the back and large on the posterior and lateral parts; some few dark spots at the margins of the ventral ridges; fins pale; caudal peduncle dark above, with several dark spots; a dark spot at base of pectoral and one on caudal peduncle below at base of lower caudal ray. Length $4_{16}^{13}$ inches. In a small specimen, $1 \frac{3}{4}$ inches in length, the spines are much longer and stronger, though absent from the ventral ridges, except the last one on each side; snout projecting considerably; gill opening very small, color with spots mostly replaced by narrow, dark, curved lines. Here described from Misaki specimens. It was not taken elsewhere by us.

This species, common throughout the East Indies, ranges occasionally northward in the Kuro Shiwo to Japan. We have a single large example from Misaki, and Bleeker records this fish from Nagasaki. The species is readily known by its short frontal spines and the translucent carapace.

(diaphanus, translucent.)

23. OSTRACION CORNUTUM Linnæus.

KONGOFUGU (ADAMANT-PUFFER).

Ostracion cornutus Linneus, Syst. Nat., 10th ed., 1758, I, p. 231; India.Schlegel, Fauna Japonica, Poiss., 1846, p. 299, pl. cxxxi, fig. 4; Nagasaki.Günther, Cat. Fish., VIII, 1870, p. 265; Natal, Zanzibar, Seychelles, Pinang, Siam, India, China, Fiji, New Guinea.-Nystrom, Svensk. Vet. Handl., 1887, p. 47; Nagasaki.-Ishiкawa, Prel. Cat., 1897, p. 3; Misaki.

Ostracion arcus Bloch and Schneider, Syst. Ichth, 1801, p. 502 (after Ostracion quadrangulatus of Seba ).-BLeEk ER, Atlas Ichth., V, 1865-69, p. 35, pl. II, fig. 3; pl. Iv, fig. 2; Java Cocos, Sumatra, Celebes, Terrate, Ceram, etc.-Goode, Proc. U. S. Nat. Mus., 1879, p. 282.

Ostracion valentini, BLEek ER, Journ. Ind. Archip., 1848 (very young). 
Head $3 \frac{1}{3}$ to 4 ; depth $2 \frac{1}{3}$ to $2 \frac{2}{3}$; D. 9 ; A. 9 ; scales on side of carapace 9 or 10 ; across widest part of ventral surface 7 ; and from ventral keel to middle of back 7 or 8 . Head deep, the profile in front very steep, nearly vertical; snout projecting $1 \frac{1}{2}$ in head and $1 \frac{1}{2}$ across forehead; eye high, $1 \frac{1}{2}$ in head and $1 \frac{1}{2}$ across forehead; interorbital deeply concave; eye about equal to its distance from gill slit in small examples and greater in large ones; mouth small, inferior; lips very thick and fleshy; teeth small, narrow, and pointed; carapace 4-angled, and in the middle of the back an inconspicuous median keel; a pair of sharp, pointed, anterior, supra-orbital spines; in the small specimens very long and the adults shorter, pointing out forward; dorsal ridges not conspicuously marked except about the low, blunt, median spine, on each side before the dorsal fin; a similar spine to the lateral dorsal spines, and between them on the back; ventral ridges plain, and terminating in a strong spine projecting backward, which is very much longer in young specimens; dorsal fin considerably in advance of anal and higher; anal beginning about midway between origin of dorsal and base of caudal; caudal very long, $1 \frac{4}{5}$ to $2 \frac{1}{2}$ in body, the edge convex and distally expanded; pectoral short, about equal to snout, and the upper rays the longest. Gill slit small, much less than eye.

Color in spirits brownish; almost all the scales above and on sides marked with dark brownish spots above and on sides; caudal peduncle above with round, dark-brown spots; above caudal with several round, large blackish-brown spots, the upper and lower parts of the fin darker than the center; dorsal, anal, and pectoral plain; snout dark, blackishbrown; lips pale. Largest specimen, $77_{19}^{11}$ inches. Two very small specimens have the dorsal and ventral ridges very pronounced, a deep, short body, the sides and upper surface strongly striated, and the caudal short, and its base rather high. Here described from Misaki specimens. It was not taken by us elsewhere in Japan. It is common in the East Indies, and we have numerous examples from Manila.

(cornutus, horned.)

\section{ARACANA Gray.}

Aracana Gray, Ann. Nat. His., I, 1838, p. 110 (aurilus).

Acerana KAup, Wiegmann's Archiv., 1855, p. 219 (same type?).

Capropygia KAUP, Wiegmann's Archiv., 1855, p. 220 (unistriata).

Kentocapros KAUP, Wiegmann's Archiv., 1855, p. 220.

Anoplocapros Kaup, Wiegmann's Archiv., 1855, p. 221 (grayi).

This genus differs from Ostracion in having the carapace open behind the anal fin. The species vary in form almost as much as do those of Ostracion. The single Japanese species belongs to the subgenus Capropygia, having spines on the ridges but none above the eye. In Aracana proper there are spines over the eye, and the abdomen is crested, while in Apoplocapros the back and belly are crested, but no spines are present anywhere.

(aracana, a meaningless name.) 


\section{ARCANA ACULEATA (Houttuyn).}

\section{ITOMAKI FUGU (REAL PUFFER).}

Ostracion aculeatus Houttuyn, Verh. Holl. Maats. Wet. Haarlem, XX, Pt. 2, 1782, p. 346; Nagasaki.-Ishikawa, Prel. Cat., 1897, p. 3; Sagami.

Aracana aculeata GüNther, Cat. Fish., VIII, 1870, p. 266; Japan.

Ostracion hexagonus Thunberg, Vet. Ac. Nya Hyndl., XI, 1790, p. 107, pl. II; Japan ("Veneni suspectus et in cibo damnatus").-Bloch and Schneider, Syst. Ichth., 1801, p. 502 (copied).

Ostracion stictonotus Schlegel, Fauna Japonica, Poiss., 1846, p. 297, pl. cxxxi, fig. 3; Nagasaki.-Bleek er, Verh. Ak. Wet., I, 1853, Japan, p. 15; Nagasaki.-Nystrom, Svensk. Vet. Handl., 1887, p. 48; Nagasaki.

Head $3 \frac{1}{2}$ to $3 \frac{3}{4}$; depth 2 to $2 \frac{1}{5}$; D. 10 to 11 ; A. 10 ; scales 8 or 9 in a series from gill opening to end of carapace, 8 across widest part of ventral surface, and 8 or 9 from middle of back to ventral ridge; scales all roughly striated; carapace strong, with 6 ridges; the dorsal fin with a broad, strong, compressed spine about halfway between the posterior margin of eye and origin of dorsal; the lateral ridges a little superior and on the posterior half of the carapace, and 2 broad, flattened spines on each side under the dorsal; ventral ridges each with a median, broad, flattened spine, posterior to the dorsal spine, and terminated finally in a more rounded posteriorly directed spine. The head is very deep, profile obliquely straight above to the tip of the snout; snout inferior, protruding little; mouth small; teeth small, narrow, and pointed; jaws subequal, lips very thick, fleshy, and papilose; eye high, large, $1 \frac{2}{3}$ in snout, $2 \frac{1}{2}$ in head, $1 \frac{1}{2}$ in forehead between eyes; nostrils small in front of eye; gill opening below the middle of the eye, from one-half to two-thirds the diameter of the eye, and greater than the space between the lower margin of the eye to its upper end; origin of dorsal only a short distance in advance of that of the anal, and also higher than the same; caudal broad and slightly convex, the edges sharp; pectoral equal to snout, the outer ray the longest, the others graduated to the innermost, which is one-half the length of the outer; caudal peduncle rather thick, its least depth from one-half to twothirds the length of the eye.

Color of the body brown, darker above, and on the back and upper parts of the sides with many blackish-brown spots nearly as large as the pupil; fins all plain; snout brownish above. Length of largest specimen $5 \frac{1}{2}$ inches. Here described from Nos. 2372, 2377, 2378, and 2382, dredged by the U. S. Fish Commission steamer Albatross in Sagami Bay.

This little trunk fish is rather common at moderate depths in the waters of southern Japan, not having yet been seen elsewhere. Our specimens are from Misaki and from Sagami and Suruga bays, where they were dredged by the U. S. Fish Commission steamer Albatross.

(aculeatus, with needle-like spines). 


\section{SUMMARY. \\ SCLERODERMI.}

Family I. Triacanthide.

1. anomalus (Schlegel).

1. Triacanthodes Bleeker.

2. brevirostris Schlegel.

2. Triacanthus Cuvier.

Family II. BALISTIDE.

3. Pachynathus Swainson.

3. capistratum (Shaw); Wakanoura, Okinawa.

4. conspicillum (Bloch and Schneider); Urakawa.

4. Pseudobalistes Bleeker.

5. flavimarginatus (Rüppell); Wakanoura.

6. undulatus (Park).

5. Balistapus Tilesius.

7. aculeatus (Linnæus); Okinawa.

8. rotundatus (Procé).

6. Canthidermis Swainson.

Family III. Monacanthide.

9. chinensis (Osbeck).

7. Monacanthus Cuvier.

8. Stephanolepis Gill.

10. cirrhifer (Schlegel); Tokyo, Misaki, Totomi Bay, Onomichi, Wakanoura, Kobe, Tsuruga, Hakata, Nagasaki.

11. japonicus (Tilesius); Nagasaki.

12. oblongus (Schlegel); Nagasaki.

9. Pseudomonacanthus Bleeker.

13. modestus (Günther); Otaru, Hakodate, Aomori, Tokyo, Misaki, Tsuruga, Kobe, Onomichi, Hiroshima, Hakata, Nagasaki.

10. Rudarius Jordan and Fowler.

14. ercodes Jordan and Fowler; Tokyo, Yokohama, Misaki, Tsuruga, Wakanoura, Onomichi, Nagasaki.

11. Brachaluteres Bleeker.

15. ulvarum Jordan and Snyder; Misaki.

12. Paraluteres Bleeker.

16. prionurus Bleeker; Wakanoura.

13. Alutera Cuvier.

17. monoceros (Osbeck); Tokyo.

14. Osbeckia Jordan and Evermann.

18. scripta (Osbeck); Kiusiu, Nagasaki.

15. Pseudaluteres Bleeker.

19. nasicornis (Schlegel). 


\section{OSTRACODERMI.}

Family III. Ostracinde.

20. gibbosum Linnæus.

16. Ostracion Linnæus.

21. immaculatum Schlegel; Tokyo, Misaki, Aburatsubo, Enoshima, Wakanoura, Hakata, Nagasaki.

22. diaphanum Bloch and Schneider; Misaki.

23. cornutum Linnæus; Misaki.

17. Aracana Gray.

24. aculeata (Houttuyn); Misaki, Sagami Bay, Suruga Bay. 


\section{$2 \mathrm{BHL}$ Biodiversity Heritage Library}

Jordan, David Starr and Fowler, Henry W. 1902. "A review of the trigger-fishes, file-fishes, and trunk-fishes of Japan." Proceedings of the United States National Museum 25(1287), 251-286. https://doi.org/10.5479/si.00963801.25-1287.251.

View This Item Online: https://www.biodiversitylibrary.org/item/32399

DOI: https://doi.org/10.5479/si.00963801.25-1287.251

Permalink: https://www.biodiversitylibrary.org/partpdf/9158

\section{Holding Institution}

Smithsonian Libraries

\section{Sponsored by}

Smithsonian

\section{Copyright \& Reuse}

Copyright Status: NOT_IN_COPYRIGHT

This document was created from content at the Biodiversity Heritage Library, the world's largest open access digital library for biodiversity literature and archives. Visit BHL at https://www.biodiversitylibrary.org. 